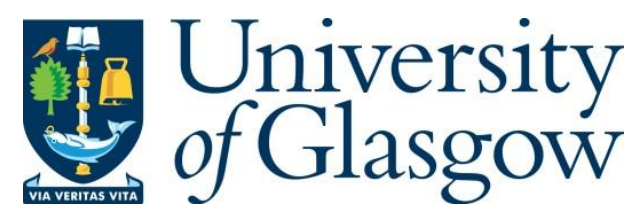

Reinsberg, B. and Westerwinter, O. (2019) The global governance of international development: documenting the rise of multi-stakeholder partnerships and identifying underlying theoretical explanations. Review of International Organizations, (doi: 10.1007/s11558-019-09362-0).

There may be differences between this version and the published version. You are advised to consult the publisher's version if you wish to cite from it.

http://eprints.gla.ac.uk/187651/

Deposited on: 4 June 2019

Enlighten - Research publications by members of the University of Glasgow http://eprints.gla.ac.uk 


\title{
The global governance of international development: Documenting the rise of multi-stakeholder partnerships and identifying underlying theoretical explanations
}

\author{
Bernhard Reinsberg, ${ }^{1,2^{*}}$ Oliver Westerwinter ${ }^{3,4}$ \\ 1 - University of Cambridge, Centre for Business Research \\ 2 - University of Glasgow, School of Social and Political Sciences \\ 3 - University of St. Gallen, Department of Political Science \\ 4 - European University Institute, Robert Schuman Centre for Advanced Studies \\ * Correspondence: Adam Smith Building, Glasgow G12 8RT, bernhard.reinsberg@glasgow.ac.uk
}

\begin{abstract}
The global governance of development increasingly relies on multi-stakeholder partnerships between states, intergovernmental organizations, and non-governmental organizations. This article takes on two tasks. The first is to describe quantitatively the institutional evolution of the multilateral development system over the past century. The second is to juxtapose four rational-institutionalist explanations for why states establish new organizations as transnational governance initiativesfunctionalism, power-oriented theories, domestic politics, and contextual design. The empirical analysis probes these explanations using the new Transnational Governance Initiatives in World Politics dataset, which combines several existing data sources to build the most comprehensive data on forms of institutionalized cooperation in global governance. The results lend most support to the contextual design view, while also yielding support for other accounts. By employing Heckman selection models, the analysis addresses potential selection bias due to unobserved correlation between state choices to create a new organization and its design. A qualitative case study further validates measurement choices and causal mechanisms. These findings have implications for theories of institutional design and development practice, specifically regarding the role of intergovernmental organizations in an increasingly interconnected world.
\end{abstract}

Keywords: global governance; multilateral development organizations; aid architecture; informal governance; transnational governance; fragmentation; trust funds;

JEL Classification: F30, F55, H87, O19

\footnotetext{
We thank Mette Eilstrup-Sangiovanni, Alvise Favotto, Matt Gordon, Christopher Kilby, Kelly Kollman, Miles Kahler, Jason Sharman, and participants of the ECPR Joint Sessions in Pisa (April 25-28, 2016), the project workshops on the Politics of Informal Governance in St. Gallen (October 6-7, 2016) and Geneva (May 19-20, 2017), and three anonymous reviewers for helpful comments. We are grateful to all interviewees for their time and their willingness to support this project. Funding from the Swiss Network for International Studies (SNIS) is gratefully acknowledged.
} 


\section{Introduction}

In 1998, health experts from the World Health Organization (WHO) called upon foreign aid donors to mobilize a massive effort to tackle infectious diseases. The G-8 pledged to take action on this call at their Okinawa summit, and mandated a transitional working group at the subsequent G-8 summit in Genoa to devise an institutional structure that would help them fulfill their pledge. ${ }^{2}$ Most donor countries were reluctant to create a new organization, but they also doubted that the United Nations (UN) system would be able to manage a major increase in foreign aid for tackling infectious diseases. Hence, donor countries decided that the new institution would be a "partnership between governments, civil society, the private sector, and people affected by the diseases." 3 They called upon other countries, private foundations, and academic institutions to join with financial resources, in-kind contributions, and shared expertise. On January 28, 2002, donors approved the framework document of a new "Global Fund" tackling three burdensome diseases-HIV/AIDS, tuberculosis, and malaria. The organization has since become a key player in global public health. When its secretariat took up operations in early 2002, the Global Fund had already received about USD 2 billion in pledges. ${ }^{4}$

The institutional structure of the Global Fund differs markedly from previous intergovernmental organizations addressing development challenges. The Global Fund was established not by international treaty but as a foundation under Swiss law and endowed subsequently with international privileges. And yet, it resembles formal intergovernmental organizations such as the WHO, as it has an independent secretariat, a governing board, and legal personality (Clarke 2014). In contrast, unlike the WHO, its governing board includes non-state actors and intergovernmental organizations (IGOs); finally, it describes itself as "a financing institution [... that does] not implement programs on the ground." ${ }^{, 5}$ Its comparative advantage is stakeholder mobilization. As one donor official said, the Global Fund "undeniably achieved more media coverage than what would have been possible [...] through traditional channels." ${ }^{\prime 6}$ To implement its programs though, the Global Fund relies primarily on the established multilaterals and their country support structures, for example WHO, UNICEF, or the World Bank. In light of these particular features, which reflect a departure from the prototypical model of formalized inter-state cooperation, the Global Fund is best described as a transnational public-private governance initiative (TGI).

In this article, we take on two tasks. First, we exploit a new dataset to describe quantitatively the institutional evolution of the multilateral development system since its inception. This allows us to elucidate the prevalence of new models of institutionalized cooperation in development and when such new institutions superseded traditional forms of intergovernmental cooperation. The data show that for a long time, development cooperation

\footnotetext{
${ }^{2}$ http://www.g8.utoronto.ca/summit/2000okinawa/finalcom.htm (Accessed October 5, 2016).

${ }^{3}$ www.theglobalfund.org/en/overview/ (Accessed October 5, 2016).

http://www.nytimes.com/2001/08/19/opinion/stinginess-onaids.html? scp=1\&sq=\%22Stinginess \%20on\%20AIDS\%22\&st=cse\&_r=0 (Accessed October 5, 2016).

${ }^{5}$ https://www.theglobalfund.org/en/overview/ (Accessed May 15, 2017).

${ }^{6}$ Written communication with a DFID staff member (December 15, 2017).
} 
took place through IGOs - treaty-based international institutions established by at least three states and featuring a permanent secretariat (Pevehouse, Nordstrom, and Warnke 2004) - for example the World Bank, the UN, and regional organizations (such as the African Union). However, since the end of the Cold War, TGIs have become the preferred modality of cooperation in development. TGIs are multi-stakeholder partnerships that formally involve states along with IGOs, non-governmental organizations (NGOs), and business actors (Westerwinter 2019c). In addition to the Global Fund, examples of TGIs include high-profile initiatives such as the UN Global Compact and less well-known ones such as the WorldFish Center. TGIs tend to produce non-legally binding policy output, which is partly a result of their multi-stakeholder nature. Furthermore, TGIs tend to be less institutionalized than IGOs, often, though not always, lacking organizational features such as independent secretariats and formally specified mechanisms for decision-making, monitoring, enforcement, and dispute settlement, which makes them "informal organizations" (Vabulas and Snidal 2013; Westerwinter 2019c; Westerwinter, Abbott, and Biersteker 2019).

Second, we juxtapose four potential explanations for why states establish TGIs. Functionalism posits that states create international institutions whose design reflects the functions they are supposed to deliver (Abbott and Snidal 1998; Haas 1964; Koremenos 2016; Koremenos, Lipson, and Snidal 2001). Power-oriented approaches posit that institutional designs reflect the interests of the most powerful states (Gruber 2000; Mearsheimer 1994; Stone 2013; Verdier 2015). Domestic politics relates design choices at the international level to the political incentives of governments at home, specifically participatory governance structures and norms that provide non-state actors with access to policy-making and implementation (Andonova 2014; Andonova, Hale, and Roger 2017; Remmer 2002; Westerwinter 2019d). Finally, we consider contextual design as a fourth approach, arguing that states do not design new organizations in an institutional vacuum but consider the existing landscape of multilateral organizations. In particular, states should be less likely to create a new organization if there is an organization that provides similar governance functions to them. Furthermore, states avail themselves of the flexible nature of TGIs to institutionalize the governance functions that even the most-similar existing organizations do not deliver (Westerwinter 2019a).

We probe the validity of these theories for design choices in the multilateral development system. We choose the development regime for various reasons. First, it is the largest in terms of the number of organizations with respective mandate. ${ }^{7}$ Second, while qualitative research has documented important trends such as the rise of TGIs for this regime, related large- $N$ analysis is lacking. And yet, such large- $N$ analysis is the only way to arbitrate among different explanations of institutional design. Third, institutional design theories in which states are the primary actors are most applicable in the development regime because states remain the most important donors to global development causes, thereby likely having the ultimate say over global governance choices.

\footnotetext{
${ }^{7}$ A related benefit is that it is relatively easy to establish whether an organization has a development mandate, given that most organizations report their activities to the benefit of developing countries on their website.
} 
Our large- $N$ analysis relies on the Transnational Public-Private Governance Initiatives in World Politics (TGIWP) dataset (Westerwinter 2019c). The TGIWP dataset filters TGIs from several data sources supplemented by a snowball procedure that draws on the websites of TGIs and other organizations. We combine the TGIWP data with expanded versions of the Correlates of War (COW) Project's data on intergovernmental organizations (Pevehouse et al. 2015) and the data on informal intergovernmental organizations originally collected by Vabulas and Snidal (2013). Our dataset thus provides the most comprehensive data for studying our research question. The data include 559 international organizations with a development mandate. To mitigate concerns about selection bias due to the partial observability of institutional design choices, we employ a Heckman selection model to jointly analyze the processes of institutional creation ('Do states create a new organization?') and institutional design ('Is this organization a TGI?'). As the junctures at which states could have created new organizations (but failed to do so) are not systematically observed, we utilize multiple imputation (Honaker, King, and Blackwell 2011) to obtain values on the main covariates in these instances.

In preview of some of our results, we find institutional design choices are best explained by a combination of all four accounts. We obtain most robust support for functionalism, poweroriented theories, and contextual design. We show these results are robust to alternative measurement of key indicators and alternative estimation methods. To illustrate the quantitative findings, we conduct an in-depth case study of the Intergovernmental Forum on Chemical Safety (IFCS) - a development TGI established in 1994. While the case analysis is consistent with all four accounts of institutional design, the contextual design view proves most useful in explaining two critical design choices - the multi-stakeholder nature of the organization and its lack of an independent technical secretariat. The case study thus undergirds the importance of the contextual design view as a complement to existing accounts of institutional choice (see, Westerwinter 2019a, for a more general treatment), while also contributing to measurement validation and further theoretical refinement of some of these accounts.

Our study advances social-scientific research in International Relations in several ways. First, we complement three well-established rational approaches to institutional design with a fourth approach that focuses on institutional context. While existing research has looked at why states design (or fail to design) specific institutional forms (Vabulas and Snidal 2013), such as dispute settlement provisions (Koremenos 2013; Koremenos and Betz 2013; Rosendorff and Milner 2001), research looking across organizational types is still in its infancy. Furthermore, we theorize how the institutional context affects institutional design choices. Our argument chimes with recent historical-institutionalist accounts that emphasize the role of history and the bounded rationality of decision-making governments (Fioretos 2017; Jupille, Mattli, and Snidal 2013). But while such work draws its conclusions from case studies of 
intergovernmental cooperation alone, we provide a large- $N$ test of a context-sensitive design perspective along with measurement validation in a qualitative case study. ${ }^{8}$

Second, we contribute to the literature on multi-stakeholder partnerships in development, which took off in response to the Johannesburg World Summit on Sustainable Development in 2002 (Andonova and Levy 2003; Favotto and Kollman 2018; Kell 2013; Thérien and Pouliot 2006). The few studies in this area that propose explanations for the rise of such partnerships focus on supply-side factors such as the institution-building efforts by budgetconstrained IGOs (Andonova 2017; Andonova, Hale, and Roger 2017; Andonova and Levy 2003; Bull, Bøås, and McNeill 2004; Hale and Roger 2014) and demand-side factors such as pressures for representation from NGOs, firms, and private donors (Bäckstrand 2006; Bulkeley et al. 2014; Elsig and Amalric 2008; Hoffmann 2011). These studies tend to overlook the relevance of a context-sensitive design perspective. Dingwerth and Pattberg (2009) use the theory of "organizational fields" (DiMaggio and Powell 1991) to explain the apparent similarity of institutional designs among TGIs, but our explanation differs from organizational fields in that it predicts increasing dissimilarity among institutions.

Third, we help substantiate popular claims in global governance, International Relations, and development policy research on the evolution of the multilateral development system. In particular, no study to date has measured quantitatively the extent to which development cooperation is organized around informal organizations, while related attempts have already been made in other areas, such as environmental regulation and climate governance (Abbott, Green, and Keohane 2016; Abbott and Hale 2014; Andonova 2010). Furthermore, some observers argue that the multilateral aid architecture has become increasingly crowded (Kharas 2007; Reisen 2010; World Bank 2008), worrying about the growing "fragmentation" that is thought to make the development regime less effective in tackling global problems (Benvenisti 2006; Biermann 2017; Biermann et al. 2009; Reinsberg 2016). Our results suggest that states are reluctant to fragment existing governance structures, even though they sometimes must do so to address burgeoning development challenges, particularly when no existing organization fulfills the intended role. Hence, rather than assuming a proclivity for institutional proliferation, we argue that states design institutions more carefully and are aware of the tradeoffs involved.

Finally, we offer methodological contributions to studies of global governance and institutional choice. First, by deploying a Heckman selection model, we address the challenge of missing counterfactuals in the analysis of institutional choices. In addition, by complementing large- $N$ analysis with a qualitative case study, we increase the validity of our findings. As the statistical model fits the data rather well, we choose a representative case for which the hypothesized mechanisms should be present. To the best of our knowledge, this is the first nested analysis (Lieberman 2005) in the sub-field of institutional design. Overall, these various methodological procedures are motivated by the aim to reduce bias in the estimates of interest to the fullest extent possible.

\footnotetext{
${ }^{8}$ Copelovitch and Putnam (2014) propose a refinement of rational institutionalism that incorporates context by measuring the number of prior bilateral treaties submitted by state parties to the UN Treaty Series. Yet, their paper focuses on treaties, whereas our analysis covers different types of organizations.
} 
We proceed as follows. Section 2 derives theoretical predictions for institutional design choices by states in global governance. The subsequent sections are empirical. Section 3 traces the institutional evolution of the multilateral development architecture based on descriptive analysis of the TGIWP data. Section 4 presents the research design. Section 5 presents regression results. Section 6 illustrates these findings with a qualitative case study. Section 7 summarizes the findings and concludes with a discussion of wider implications for global governance research.

\section{Drivers of multi-stakeholder partnerships}

The defining feature of TGIs is that their governance structures involve multiple stakeholders (Andonova 2010; Bull, Bøås, and McNeill 2004; Hale and Roger 2014). In addition, they tend to lack formalization with respect to the organizational features typically associated with IGOs and the degree to which their policy outputs are legally binding (Westerwinter, Abbott, and Biersteker 2019). We now draw on various rationalist approaches to identify the conditions under which states - as the primary decision-making actors in global governancechoose TGIs to institutionalize cooperation. ${ }^{9}$ Conceptually, this choice is a two-stage process. In the first stage, states decide about whether or not to create a new organization. In the second stage, they select an organizational type. ${ }^{10}$ The various accounts emphasize different factors affecting these choices, including functional demands ("functionalism"), the interests of powerful states ("power-oriented theories"), domestic political institutions ("domestic politics"), and the pre-existing institutional architecture ("contextual design").

\section{Functionalism}

Functionalists argue that design choices reflect the most efficient way to address a given problem (Koremenos 2016). A key functionalist determinant of institutional design is "problem structure." To the extent that development challenges are increasingly complexpartly as a result of economic interdependence (Keohane and Nye 1977) - the transaction costs of creating new organizations increase (Hale, Held, and Young 2013)-despite the potential for issue linkage that may facilitate institutionalized cooperation (Keohane 1984). In terms of design choices, issue complexity makes purely intergovernmental solutions ineffective because complex problems require the involvement of all relevant stakeholders that contribute specific expertise, relevant capacity, and financial resources. To that end, states require more flexible governance structures. IGOs do not provide such flexibility because they can only admit state members, regardless of attempts to facilitate participation of

\footnotetext{
${ }^{9}$ Our theoretical discussion focuses on the strategic choices of states. States are central players in the creation and design of TGIs and IGOs and their preferences have a strong impact on how institutional fields and global governance as a whole develop. Importantly, if they decide to engage in new institutionalized cooperation, states can choose whether they want to use a TGI or IGO. Other actors have more limited institutional options. It is, therefore, useful to focus on the agency and strategies of states in the theoretical argument. Future research may want to examine the strategies and institutional choices of non-state actors in greater detail to complement our analysis.

${ }^{10}$ Probably this is a simplification as states might take multiple decisions over individual design features. We will not disaggregate the second stage further here.
} 
non-state actors (Tallberg, Sommerer, and Squatrito 2016). Conversely, TGIs allow states to respond flexibly to newly emerging development issues and to find solutions to problems that cut across many different issue areas.

Other determinants of institutional design include the number of states, the homogeneity of state preferences, and various dimensions of uncertainty (Koremenos, Lipson, and Snidal 2001; Lipson 1991; Rosendorff and Milner 2001). ${ }^{11}$ As the number of states increases, institutionalized cooperation is less likely to emerge as transaction costs increase. However, if a new organization is created, it will more likely be an IGO as the number of member states increases. This is because larger groups of states face more severe collective action problems and hence prefer higher levels of delegated authority and formal structure to resolve these problems (Koremenos 2008, 154). In contrast, small numbers allow states to benefit from enhanced flexibility - bringing up any issue that they may desire and addressing issues in a timely manner - and the discretion entailed in decentralized policy implementation.

As regards state preferences, more heterogeneous state preferences increase the likelihood of disputes and the risk of policy-making stalemate (Hale, Held, and Young 2013). While heterogeneous preferences reduce the likelihood that a new organization will be created, a given organization will be more formalized under such circumstances because states must fear that cheating will be more prevalent. Conversely, more harmonious preferences instill trust among states and thus lessen the need for centralized enforcement and dispute settlement (Eilstrup-Sangiovanni 2015).

To summarize, according to functionalism, states will create a new organization under the following conditions:

- The problem at hand is limited to one (or very few) issue area(s).

- The number of states is small.

- State preferences are relatively homogenous.

States will design an organization as a TGI under the following conditions:

- The problem at hand cuts across several issue areas.

- The number of states is small.

- State preferences are relatively homogenous.

\section{Power-oriented theories}

Power-oriented theories of international institutions recognize that power is unevenly distributed in the state system and argue that global governance arrangements are the direct

\footnotetext{
${ }^{11}$ Uncertainty may be about state preferences, state behavior, and the state of the world (Koremenos, Lipson, and Snidal 2001). The first two should be less relevant in development, as states have incentives to make their actions for development visible. Uncertainty about the state of the world is relevant but hard to measure given that (unmeasurable) state perceptions matter here. We will capture uncertainty empirically using a number of issue area dummies.
} 
result of how state power is distributed (Grieco 1988; Krasner 1991; Mearsheimer 1994). State power derives from valuable outside options, the size of the domestic market, and material capabilities (Gruber 2000; Kaya 2015; Voeten 2001).

The prevalence of powerful countries makes institutionalized cooperation less likely. To be sure, some scholars in the tradition of hegemonic stability theory hold that powerful states can coerce weaker states into institutionalized cooperation upheld by them (Gilpin 1981; Keohane 1980; Kindleberger 1973; Webb and Krasner 1989). However, apart from other challenges to hegemonic stability theory (Keohane 1984), there is no reason to believe that powerful states would prefer institutionalized governance over informal governance. Indeed, powerful states can coerce weaker states to comply with specific policies by pure threats, without the help of an international organization (Gruber 2000; Mearsheimer 1994; Steinberg 2002). In general, powerful states themselves are better off by not being bound by formal rules, as violating them may cause reputational damage (Axelrod 1984). Furthermore, less powerful states have no means to impose formal rules upon powerful ones. Therefore, new organizations are less likely to emerge to the extent that powerful states are present and state power is unevenly distributed.

Furthermore, power politics also tilts institutional design choices in the favor of TGIs. To be sure, powerful states may have some incentives to formalize cooperation - for instance as a credible commitment device (Ikenberry 2001; Rodrik 1995; Stone 2011). However, they will concede to powerless states on secondary issues at best (Stone 2011; Verdier 2015; Voeten 2001). Powerful states for the most part prefer informal designs and non-legally binding agreements (Thompson 2009). Informal organizations impose fewer constraints on power and hence increase the returns to power, which is particularly attractive for powerful states (Westerwinter, Abbott, and Biersteker 2019). For instance, decision-making by consensus is favorable to powerful states as it gives them de-facto veto power without making dissent explicit (Gould 2017). Powerful states also wish to prevent robust enforcement provisions because it limits their returns to power politics. They also tend to oppose formalized dispute settlement because it empowers less powerful states by offering a legalized procedure to enforce their claims which, if ignored by the powerful state, would harm its reputation (Simmons 2000). For similar reasons, powerful states also prefer non-legally binding policy output.

To illustrate the above points, the United States under its current administration provides a good example. In his first foreign policy speech, US president Donald Trump stated that under his administration, America will never enter "into any agreement that reduces our ability to control our own affairs," arguing further he was "skeptical of international unions that tie us up and bring America down."12 Consequently, Trump cut US funding for several UN organizations. ${ }^{13}$ Yet, as a powerful state, the United States has been reaping the benefits from informal organizations. The Proliferation Security Initiative-albeit not a development TGIs - provides an example. Launched by former US president George Bush in 2003, the initiative aims to control proliferation of weapons of mass destruction from states to non-state

\footnotetext{
${ }^{12}$ http://time.com/4309786/read-donald-trumps-america-first-foreign-policy-speech/ (accessed October 1, 2018).

${ }^{13} \mathrm{https}$ ://www.undispatch.com/heres-trumps-budget-request-impact-united-nations/ (accessed October 1, 2018).
} 
actors. It requires participant states to share information concerning suspected proliferation activities, strengthen national legislation, and undertake joint missions to interdict shipments of such weapons. The initiative lacks a legal framework and clear definitions - deliberately so to provide maximum flexibility to participants in acting upon alleged acts of illicit proliferation (Eilstrup-Sangiovanni 2015).

Both the preferences of powerful states and the distribution of power among states predict institutional design outcomes. For the reasons discussed above, institutionalized cooperation is more likely to take the form of a TGI if it includes powerful member states. Furthermore, a more unequal power distribution among member states is also conducive to a TGI design because the powerless countries - oftentimes dependent on aid transfers from powerful countries-have little choice but to go along with the design preference of the powerful states. $^{14}$

Following the above discussion, power-oriented theories would expect the creation of a new international organization under the following conditions:

- The average participating state is less powerful.

- Power across member states is evenly distributed.

Furthermore, power-oriented theories would expect states to design a given organization as a TGI under the following conditions:

- The average participating state is powerful.

- Power across member states is unevenly distributed.

\section{Domestic institutions}

Finally, domestic political institutions, notably regime type, may affect design choices at the international level. The effect of regime type on the emergence of institutionalized cooperation is ambiguous. On the one hand, the logic of two-level games suggests that democracies have smaller win-sets, thereby reducing the range of potential outcomes involving institutionalized cooperation (Putnam 1988). On the other hand, democracies embody cooperative norms that should facilitate international cooperation (Remmer 2002). Newly democratic states may also promote a new international organization as it would provide them with a credible commitment device (Mansfield and Pevehouse 2012). However, their lacking ability to make credible commitments likely prevents other states to form an organization with them, which implies a negative relationship between regime type heterogeneity and the emergence of new organizations. In other words, if both democratic as well as non-democratic countries are involved in an attempted cooperative effort, the difficulties to credibly commit faced by non-democracies make the occurrence of new institutionalized cooperation less likely.

\footnotetext{
${ }^{14}$ Obviously, powerless countries might have no interest to form a new organization under these parameters, which would predict that organizational creation is less likely when power differences are large. We will return to this issue in the empirical analysis.
} 
In addition, domestic political institutions can affect the specific form of cooperative endeavors (Acharya 2016b; Raustiala 2005; Westerwinter 2019d). ${ }^{15}$ A group of states should design a new organization as a multi-stakeholder partnership if it is more democratic for two reasons. First, a demand-side argument holds that democracies make it easier for NGOs to organize, mobilize, and participate in global governance (Andonova 2014; Andonova, Hale, and Roger 2017; Kahler 2016). Second, a supply-side argument holds that democracies have embraced the right of non-state actors to participate in political decision-making, both domestically and internationally. Whereas IGOs are limited in their extent to which they can include non-state actors into decision-making processes (Dingwerth, Schmidtke, and Weise 2011; Tallberg, Sommerer, and Squatrito 2016), TGIs provide governance structures that can accommodate demands for meaningful participation from non-state actors (Andonova, Hale, and Roger 2017). We therefore argue that states collectively prefer to cooperate through TGIs - rather than IGOs - to the extent that their domestic political regimes are democratic.

Further, regime type heterogeneity also affects the choice of a TGI as mode of institutionalized cooperation. Given the commitment problems of non-democratic governments, democratic governments that contemplate to cooperate with non-democracies will need assurances that they will comply with the rules and policies that are agreed. Domestic institutions cannot provide these assurances. Thus, democracies will push for formalized institutional structures that provide legally binding rules accompanied by a centralized monitoring and enforcement apparatus to safeguard the cooperation from defection by their non-democratic partners. As a result, if states with heterogeneous regime types initiate new institutionalized cooperation, it is less likely to take the form of a TGI since TGIs are not well-suited to provide the assurances required by democracies.

In summary, states are more likely to create a new organization if the maximum difference in regime types is large (while the effect of average levels of democracy is ambiguous). A new organization is more likely to take the form of a TGI under the following conditions:

- The average member country is more democratic.

- A small difference in regime types across member states.

\section{Contextual design}

A contextual design perspective assumes that states make institutional choices in view of the existing global governance architecture. In particular, we argue that states want to avoid functional duplication to minimize transaction costs, especially when the pre-existing institutional landscape is crowded. This argument builds on previous work emanating in response to rational institutionalism and arguing that a denser institutional context can facilitate more formalized cooperation in subsequent stages of institutionalized cooperation (Duffield 2003; Jupille, Mattli, and Snidal 2013; Copelovitch and Putnam 2014; Gehring and Faude 2014; Fioretos 2017).

\footnotetext{
${ }^{15}$ In fact, studies in the New Interdependence Approach tradition examine how domestic institutions affect the ability of politicians to construct the rules and norms governing interdependent relations and how interdependence itself affects domestic institutions (Farrell and Newman 2014; Fioretos 2011; Slaughter 2004).
} 
We borrow from this line of thought to argue that states design new organizations that complement the governance functions of existing organizations. This distinguishes our argument from the previous works which imply that deeper context facilitates deeper cooperation, which is not necessary in our account. Our argument here resonates with the work of Gehring and Faude (2014) who emphasize the emergence of an institutionalized division of labor in areas of overlap between IGOs. We expand the discussion of institutional complementarity toward the relationships between formal and informal modes of governance and the creation of TGIs. Thus, we argue and show empirically that concerns about complementarity are not only affecting the operations of existing institutions but are important factors in the initiation and design of new institutions. Why would states want new organizations to be complementary to the existing ones? Despite individual incentives for "forum-shopping" - the practice of (powerful) states to shift policy discussions to governance venues where they expect the greatest benefit for themselves (Busch 2007; Drezner 2009; Dür, Baccini, and Elsig 2013; Helfer 2004)—states collectively want to avoid duplication of tasks in the multilateral system as it increases the cost of development cooperation (Cooley and Ron 2002; Drezner 2009; Panneels and Beringhs 2005). For example, Drezner (2009) argues that regime complexity can undermine the significance of organizations by diluting the power of previously constructed focal points promoting rule-based cooperation. An example is the declining "focality" of the WHO brought about by the proliferation of global health initiatives (Hanrieder 2015). Furthermore, overlapping mandates across organizations bear the risk of conflicting commitments that will lessen the sense of legal obligation among states to comply with their commitments (Morse and Keohane 2014). Finally, regime complexity raises transaction costs for all actors (Raustiala and Victor 2004).

The above discussion implies the following hypothesis regarding the emergence of new organizations given the institutional context:

- States are less likely to create a new organization if an existing organization already performs highly similar tasks in a given issue area.

While creating new organizations may sometimes be necessary, states can avoid task duplication by letting these organizations only perform certain functions but relying on existing organizations to perform other functions. Therefore, TGIs tend to be complementary to IGOs with respect to their task structure. Given that IGOs - through maintaining a professional international bureaucracy-have a competitive edge in the implementation of large-scale policies and the production of technical knowledge, states establish TGIs specifically for the purposes of raising awareness for new issues, promoting policy consensus, and harnessing the value of partnerships. ${ }^{16}$

\footnotetext{
${ }^{16}$ While, in principle, both new IGOs and TGIs can be designed to enhance institutional complementarity in a given governance field, TGIs are particularly suitable and attractive devices to achieve institutional complementarity. TGIs are a different species of cooperative form whose comparative advantage is convening power. Because of their more restrictive membership structure IGOs are less well-equipped to act as convenors. In addition, the complexity of contemporaneous challenges is such that it is ever less possible to foresee which governance functions will actually be needed and that these functions need to be adapted to changing circumstances. Again, IGOs are less convenient to states for that purpose, given much higher costs for
} 
The Global Fund provides a case in point. While traditional IGOs perform an implementing role, the Global Fund is tasked with resource mobilization and program monitoring. In line with recent scholarship, the relationship between the Global Fund and its associated organizations can be called "orchestration," defined as "the mobilization of an intermediary by an orchestrator on a voluntary basis in pursuit of a joint governance goal" (Abbott et al. 2015). For example, the Global Environment Facility (GEF) is an orchestrator that uses a range of intermediaries to deliver its assistance (Graham and Thompson 2016). While the GEF mobilizes resources for climate-related development activities and allocates these resources to projects, the traditional IGOs (so-called "GEF agencies") prepare bids for GEF funds with local partners (Bayer, Marcoux, and Urpelainen 2015; Graham 2017; Michaelowa, Reinsberg, and Schneider 2018).

The implication of this argument is that newly established TGIs will look different from even the most-similar existing organizations as they are designed to perform different tasks in a given issue area. ${ }^{17}$ If it is true that TGIs partner with existing IGOs-to benefit from their relative organizational strengths - a more specific hypothesis can be formulated in that newly created TGIs would look dissimilar to existing IGOs in terms of their task profile in a given issue area. In summary, the above discussion yields the following hypotheses regarding design choices:

- A new organization is less likely to take the form of a TGI to the extent that an existing organization performs similar tasks in a given issue area.

- A new organization is less likely to the form of a TGI to the extent that an existing IGO performs similar tasks in a given issue area.

\section{A new dataset to study the historical development of the multilateral aid architecture}

In this section, we use a new dataset to describe the institutional evolution of the multilateral development system. 'Development' is a particularly relevant issue area given that most international organizations contribute to it. To identify as many as possible international development organizations, we draw on the TGIWP dataset (Westerwinter 2019c). This dataset was obtained by identifying TGIs in several existing databases on transnational institutions, including the Global Solution Networks data (Abbott and Hale 2014), data from MSI Integrity and the Duke Human Rights Center at the Kenan Institute (2017), the transnational climate governance initiatives data (Michaelowa and Michaelowa 2017), the orchestration of transnational climate change data (Hale and Roger 2014), the Global Sustainability Partnership Database (Pattberg et al. 2012), and the multi-bi aid data (Eichenauer and Reinsberg 2017). ${ }^{18}$ These cases were complemented by TGIs identified

\footnotetext{
institutional or policy change in comparison to TGIs. Thus, pursuing institutional complementarity with respect to existing IGIOs can be achieved more effectively and at lower costs using TGIs rather than new IGOs.

${ }^{17}$ Note how this differs from the prediction of a sociological account in which organizations within a field become more similar due to mimetic isomorphism (Di Maggio and Powell 1991).

${ }^{18}$ For a full list of sources, see Westerwinter (2019a).
} 
through a snowball procedure based on the websites of TGIs and other organizations. ${ }^{19}$ For comparative purposes, we combine the TGIWP data with data on formal IGOs - the most recent version of the COW Project's data on intergovernmental organizations (Pevehouse et al. 2015) - and informal IGOs (Vabulas and Snidal 2013). ${ }^{20}$ This dataset offers the most inclusive collection of international organizations to date. For the development sector, it includes historical records of 559 organizations, consisting of 196 IGOs, 49 IIGOs, and 314 TGIs.

While the data provide a high-level view of organizational types in the development system, they mask what happens within organizations. For instance, the data do not capture to what extent existing organizations expand their mandates over time-whether as a result of mandate expansion or agency slippage (Alexandroff and Cooper 2010; Florini 2011; Grabel 2011; Moschella 2011). The data also do not include agency trust funds, which are quasiinternational institutions established under the institutional law of a host IGO in order to support new activities. In addition, the data also disregard inter-organizational relations, specifically at the operational level (Biermann and Koops 2017). The data also overlooks joint programs between IGOs unless they are institutionalized through intergovernmental agreements. Further, the data necessarily underestimate the true amount of informality, specifically the forms of informal processes that remain below the radar of the public. ${ }^{21}$ Finally, the data do not capture budgetary growth but rely on raw counts of organizations to reflect developments in the multilateral development architecture, thus potentially inflating the significance of TGIs. ${ }^{22}$

Despite these limitations, the data allow for the first large-N analysis of the institutional evolution of the multilateral development system over the past century. The multilateral development system came into existence only after World War II, but continuously expanded ever since. Its emergence is linked to the concept of "foreign aid"-a resource transfer from developed countries to less developed ones with the aim of increasing living standards - while its further evolution is influenced by the rise of new ideas and the evolving meanings of what "development" is about, from economic growth and industrial development, to human development, human rights and political freedom, and global public goods.

In terms of its institutional evolution, the development regime has progressively expandedfrom 18 organizations with activities in development in 1945 to 473 organizations in 2017.

\footnotetext{
${ }^{19}$ Westerwinter (2019a) provides extensive details on the sample generation, operationalization of variables, and a broad range of descriptive statistics.

${ }^{20}$ We thank Jon Pevehouse for sharing the data prior to their public release.

${ }^{21}$ Examples of informal groups in development not covered by the data are the "Geneva group" —an alliance of originally five states (and today having 18 member states) to usher budgetary restraint at the UN agencies and to promote UN reform (Blanchfield 2008). Another informal club is the "Utstein Group", established in 1999 by Canada, Germany, the Netherlands, Norway, Sweden, and the United Kingdom, with a commitment to "promoting increased coherence, coordination and cooperation on various issues including those activities variously characterized as conflict prevention, conflict management, and peacebuilding” (OECD 2004).

${ }^{22}$ However, TGIs play an important role in resource mobilization and thus often serve as "points of entry" of bilateral donor funds (Reinsberg 2017). It would thus be problematic to consider administrative budgets alone, which would over-represent IGOs.
} 
The end of World War II marked a foundational moment for the regime, given the creation of four new IGOs - the UN, the WHO, the World Bank, and the International Monetary Fund (IMF). The rate of new IGO entrants into the development system remained relatively high for several reasons. First, following the rapid recovery of Europe, many European countries themselves became donors. The entry of additional donors into the system made informal coordination necessary, leading to the establishment of the Donor Assistance Committee (DAC) that became part of the Organization for Economic Cooperation and Development (OECD) in 1961. Second, to respond to the special needs of developing countries, donors created the International Development Association (IDA) - the first concessional development fund, managed by IBRD staff - and other regional development banks (Manning 2014). Various funds and programs at the UN level were formed, covering issues such as industrial development, agricultural productivity, environmental protection, and human development. Third, as developing countries felt excluded from the governance processes of these organizations, they established new institutions to underpin their own understandings of development, notably the UN Conference for Trade and Development (UNCTAD) - an IGO serving as intellectual spearhead of the informal G-77 group of developing countries to counter the Western ideological hegemony. The rate of establishment of new IGOs remained stable even in the 'lost decade', which followed the two oil price shocks and the breakdown of the Bretton Woods order in the 1970s. The bulk of new IGOs was the result of efforts to promote regional integration, while a few IGOs followed from UN conferences by which the UN kept trying to draw public attention to new development challenges and lobbied donors to create new funds and programs, for example the International Fund for Agriculture and Development (IFAD). ${ }^{23}$

[Figure 1 here]

Since the end of the Cold War, however, the modalities of cooperation have moved away from IGOs, notably toward TGIs (and to a lesser extent toward informal IGOs). The data show that as the establishment of new IGOs leveled off, TGIs have been exploding since the end of the Cold War (Figure 1). Given this growth, TGIs have been outgrowing IGOs since 2002 - the year in which the Global Fund started its operations. Even the recent institutionbuilding efforts by rising powers, which led to the creation of the New Development Bank (NDB), established by the five BRICS countries, and the Chinese-led Asian Infrastructure Investment Bank (AIIB) (Humphrey 2015), do not alter the general picture. In fact, they further reinforce the trend toward informalism with clubs like the g7+, BRICS, and IBSA Forum (Kahler 2013). ${ }^{24}$

The takeoff of TGIs is reflected in the growing presence of private actors in the multilateral development system (Büthe and Cheng 2013). As many donor governments reduced their financial support for IGOs, private donors began to fill the void by launching partnership funds with IGOs. For example, in 1998 the UN accepted a donation from US philanthropist

\footnotetext{
${ }^{23}$ IFAD was established following UNGA Resolution 32/107 in 1978 and the 1974 World Food Conference that was held in response to the famine in Bangladesh.

${ }^{24}$ The $\mathrm{g} 7+$ is an informal association of seven fragile states established in 2008 with the aim of raising awareness for fragility and mobilizing donor support (Marah 2015).
} 
Ted Turner, who made available USD 1 billion to support a UN Fund for International Partnerships (UNFIP) and the UN Foundation (Bull, Bøås, and McNeill 2004). Through the Global Compact, the UN has intensified links with private actors (Berliner and Prakash 2015; Kell 2013; Thérien and Pouliot 2006). Private donors, notably the Gates Foundation, was critical to the establishment (and rapid takeoff) of the Global Fund. In fact, global philanthropists have become important donors particularly in global public health (Fidler 2016).

While the growth of TGIs and the relative decline of IGOs is the most apparent trend, the data show that the multilateral development system also has transformed in less visible ways during the past century. In particular, there is evidence that the system has become less universal in terms of its state membership early on. The IGOs established in the first decade after World War II all enjoy broad membership, perform tasks that none of the existing organizations had delivered, and feature a high level of institutionalization. In contrast, the IGOs created later are deficient in most of these dimensions. For instance, the DAC is a club of rich donors; UNCTAD was pioneered by a group of developing countries; and all regional organizations are exclusive by design. The fraction of states that participated in newly created IGOs bottomed at around $20 \%$ at the end of the Cold War but rose again after it. Interestingly, this was not at the expense of depth, as institutional formalization of IGOs-specifically regarding independent secretariats, monitoring mechanisms, and decision-making procedures-has generally increased after the Cold War. ${ }^{25}$ The perhaps most welldocumented IGO foundation in the post-millennium era is the International Renewable Energy Agency (IRENA) - an IGO mandated to promote the adoption of all forms of renewable energy by conducting policy analysis and providing technical assistance (Colgan, Keohane, and van de Graaf 2012). With all major design features formally institutionalized, this case fits the general trend well.

The apparent consequence of the recent TGI growth is a growing fragmentation of the multilateral development system, i.e., the governance of development is increasingly marked by a patchwork of institutions that differ in their characteristics, member configurations, as well as policy and geographical scope (Raustiala and Victor 2004; Biermann et al. 2009; Keohane and Victor 2011). The explosion of TGIs is linked to increased fragmentation because TGIs are generally less inclusive and less representative of the state community, as they tend to be dominated by Western donors. The data demonstrate that TGIs are dominated by affluent countries, notably the United States (200 memberships), the United Kingdom (151 memberships), Germany (119 memberships), and the Netherlands (110 memberships), while China, Kenya, and South Africa as the first non-DAC countries in this list are less engaged in such initiatives (with around 50 memberships each). Overall, these patterns chime with previously observed trends of declining universalism, or "minilateralism" (Bernstein 2013; Falkner 2016; Kahler 1992). ${ }^{26}$

\footnotetext{
${ }^{25}$ See Figure A1 in the supplemental appendix.

${ }^{26}$ For an analysis of issue-task similarity of new entrants to the regime over time, see Figure A2.
} 


\section{Research design}

Institutional design in global politics is a two-stage process. In the first stage, states decide whether a new organization is necessary. In the second stage, given their decision to create a new organization, they select an organizational type. A key challenge is that only those organizations (and their organizational types) are ever observed which states decided to create. Conversely, the set of organizations that did not come into existence is unknown. After introducing the main variables for the statistical analysis, we will explain below how we address the partial observability problem.

\section{Dependent variables}

The ultimate outcome of interest is a categorical variable indicating whether a given organization is designed as a TGI. A TGI is an international institution that includes at least one state or IGO, one business actor, and one $\mathrm{NGO}$, which is transnational in nature and which performs tasks that are related to governing global or transnational problems (Westerwinter 2019c). TGIs differ from IIGOs, which are international institutions characterized by explicitly shared expectations among loosely associated state members who participate in regular meetings but without significant formal institutionalization (Vabulas and Snidal 2013). Notably, IIGOs do not formally include non-state actors in their governance structures. In addition, TGIs also differ from IGOs, which are defined as international organizations established by at least three member states through formal treaty and supported by a permanent secretariat and corresponding headquarter (Pevehouse, Nordstrom, and Warnke 2004). For the main analysis, we employ a binary TGI indicator for which the relevant comparison group includes IGOs. We also employ an alternative operationalization for robustness tests in which the comparison group includes both IGOs and IIGOs. Both indicators yield very similar results.

In addition, we use the TGIWP dataset to construct an ordinal index of organizational structure, which reflects the degree to which institutional features commonly associated with highly structured IGOs are present in a given organization. This allows us to assess whether an organization has an independent secretariat, whether it specifies decision-making procedures, whether it monitors the behavior of its participants, whether it has enforcement provisions to restore state compliance, and whether it has an institutionalized dispute settlement mechanism. The TGIWP dataset collects this information based on human coding of founding documents, official websites, donor reports, and research papers on the respective international organizations. For each design feature being present, the index increases by one point. In line with expectations, IGOs score highest on this index (2.19), while IIGOs (0.47) and TGIs (0.74) score lower due to their relative lack of organizational structure (Table 1).

[Table 1 here]

\section{Independent variables}

We include varying sets of variables corresponding to alternative explanations for design choices of international organizations. Capturing tenets of functionalism, we include the (logged) NUMBER OF ISSUES that an organization addresses. we expect a positive relationship 
with informality, given the well-known tradeoff between broader mandates and deeper commitments (Gilligan 2004). This variable may also serve as proxy for issue complexity and uncertainty since multiple purposes increase ambiguity, with potential effects on structural features (Abbott and Snidal 2000; Best 2012; Jojarth 2009). Furthermore, we include the logged NUMBER OF MEMBER STATES, expecting a negative sign because cooperation involving many states is less likely to be informal. To measure PREFERENCE HETEROGENEITY, we compute the maximum ideological distance across member states based on ideal-point estimates from UN General Assembly voting patterns (Bailey, Strezhnev, and Voeten 2015). We expect a negative sign because greater ideological distance implies less harmonious preferences, which makes informality less likely.

Two variables are used to capture power politics. First, to measure PowER prevalence in an organization, we use the logged average GDP of its member states. To capture POWER DIFFERENCE, we use the logged difference of the highest GDP (for the most powerful country) and the lowest GDP (for the least powerful country). Underlying data for this variable are available from the World Development Indicators (World Bank 2015).

To capture domestic institutions, we include two measures. First, we include the average level of democracy among the member states, measured by the Polity IV index (Marshall, Jaggers, and Gurr 2010). A higher level of democracy will provide non-state actors with more opportunities to participate in global governance processes, and such groups will also be more able to seize these opportunities as they are active at the domestic level. We therefore expect a positive relationship between (average) POLITY IV and the choice of TGI. Second, we include the difference between the maximum and the minimum of the Polity IV score across the membership of the organization. We expect a negative relationship between POLITY IV DIFFERENCE and the choice of TGI, which is the result of the commitment value of democratic institutions. In particular, autocratic states cannot credibly commit to certain policies as they face comparatively fewer veto players to change policies. Therefore, democratic states will seek reassurance from these states through formal commitments and organizational structures that informal organizations (such as TGIs) are unable to afford.

To test whether design choices are contingent on existing institutions, we measure for any given organization the extent to which previously existing organizations operate in similar issue areas and provide similar governance functions in these areas. ${ }^{27}$ There is useful variation in issue areas as organizations can be active in other issue areas, despite already being active in development. We first compute the cosine similarity of the issue area profiles between a given organization and every previously existing organization, i.e. organizations that were created prior to the founding year of a given institution and did not cease to exist up until this year. Cosine similarities range from zero (indicating orthogonal portfolios) to one (identical portfolios). We then compute the cosine similarity over governance task profiles for all pairs of organizations. Finally, we employ element-wise multiplication of both vectors and identify

\footnotetext{
${ }^{27}$ The database distinguishes eight issue areas (security, environment, health, human rights, trade and commerce, finance, social affairs, and technical issues) and eight governance functions (gathering information, agendasetting, service provision, funding, capacity-building, standard-setting, policy implementation, and monitoring behavior). This implies any organization can be characterized by a 16-dimensional vector of issue-task combinations.
} 
the maximum among paired organizations. In this way, we obtain for each organization a scalar value which corresponds to the degree of issue-task similarity with respect to the mostsimilar previously existing organization, labeled MOST-SIMILAR PREVIOUS IO.

All covariates are measured at the foundational year of a given organization, ${ }^{28}$ which means that time information is integrated even though the analysis is cross-sectional. In addition to the correlates of interest, we include seven decennial period dummies to account for global trends in design choices, corresponding to the periods 1945-54, 1955-64, 1965-74, 1975-84, 1985-94, 1995-2004, and 2005-17 (the baseline being the pre-1945 period). We also control for the (logged) NUMBER OF STATES in the system (Barnett, Pevehouse, and Raustiala 2016; Hooghe and Marks 2015; Ingram and Torfason 2010). We use heteroskedasticity-robust standard errors for inference. Arguably, most correlates are potentially endogenous as they are based on the set of member states of a given institution alone. While this is an approach commonly adopted in this literature (Allee and Elsig 2014; Copelovitch and Putnam 2014; Koremenos 2016), it is important to not interpret the effects of these variables causally but to consider them as indicative of the characteristics of various institutional types. ${ }^{29}$ Unless otherwise stated, variables are drawn from the TGIWP data. Table 2 presents descriptive statistics of the main variables used.

[Table 2 here]

\section{Selection model}

As outlined above, the analysis faces the challenge of partial observability in the outcome of interests. In other words, conducting the analysis only for observed organizations may yield biased estimates, specifically if unobserved variables induce correlation between organizational design and the decision to create a new organization. This problem can be addressed using a selection model that explicitly models the first stage (Heckman 1976). Specifically, we employ a bivariate probit model as the dependent variables in both stages are binary. However, the model cannot be estimated on the observed sample alone because the first-stage outcome is constant.

What is the set of potential organizations that were never created? To induce variation in firststage outcomes, we assume that organizations can plausibly be located within the space that combines issue areas and governance tasks. We thus draw random profiles of issue areas and governance tasks ${ }^{30}$ and let these observations correspond to the organizations that were never created and add them to our sample. As the covariates for these non-existing organizations are not observable, we generate five rectangular datasets of those covariates using multiple imputation (Honaker, King, and Blackwell 2011). We then conduct bivariate probit analyses using these five datasets and aggregate the results, taking into account the additional

\footnotetext{
${ }^{28}$ The obvious exception is the contextual design variable, which takes into account all information up to the foundational year.

${ }^{29}$ The ideal approach would be to measure all variables among the potential members of an organization. Yet, as it is unclear what the set of potential members is, this approach to theory-testing is not feasible.

${ }^{30}$ Formally, a profile is an $n$-tupel $(n=16)$ of binary variables, given 8 issue areas and 8 governance tasks.
} 
uncertainty that arises from imputation (Rubin 1987). ${ }^{31}$ In other words, to circumvent selection bias induced by confounding residual correlation between institutional creation and institutional design, we create additional observations in the first stage that correspond to 'proposal organizations' that were never created. This appears to be the most appropriate remedy to the selection problem because it analytically separates the decision to create an organization from the decision on its design. For our purpose, it is preferable to a potential alternative approach which builds on the assumption that an organization of a given type (e.g., TGI) could also have been created as another type (e.g., IGO) given identical covariates (see Reinsberg, Michaelowa, and Knack 2017, who adopt this approach in the context of different trust funds). By construction, this alternative approach yields insignificant predictors for the first stage because the same covariates predict both the success and failure of a creation of an organization-which is why we prefer the former approach. ${ }^{32}$

While the Heckman selection model is a standard remedy against selection bias, it is known to be more consistent if the first stage includes an exclusion restriction (Sartori 2003) - a variable that correlates with institutional creation but not organizational types. We argue that the (logged) number of organizations created in a given year fulfills these criteria. ${ }^{33}$ Empirically, the correlation is highly positively significant $(p<0.01)$; the intuition for this result is that states create new organizations when the historical conditions to do so are favorable, which leads to a clustering of foundational years. Furthermore, elevated rates of institutional creation do not per se predict which types will be chosen-neither theoretically nor empirically. ${ }^{34}$

\section{Quantitative analysis}

Table 3 presents the full set of results. The upper part of the table corresponds to the first stage, while the lower part presents the second stage. Columns correspond to all possible combinations in the usage of issue area and governance task dummies. All regressions include the number of states in the system and period dummies as basic control variables. Some predictors are remarkably robust across the various models.

Functionalism fares moderately well. Consistent with functionalist expectations, institutional creation is less likely in the presence of issue area complexity $(p<0.01)$. The number of member states is not a robust predictor of institutional creation, although the direction of the effect is correct. Preference heterogeneity is statistically significant $(p<0.05)$ but puzzlingly positively related to institutional creation. However, preference heterogeneity correctly

\footnotetext{
${ }^{31}$ We add $\mathrm{N}_{1}=2,000$ observations in the first stage. This number is arbitrary but not consequential for the findings. Note that the second stage is still based on only the observed organizations $\left(\mathrm{N}_{2}=559\right)$, but its estimates take potential unobservable selection effects into account.

${ }^{32}$ Nonetheless, for the purpose of testing robustness, we implement this alternative approach in the Appendix and confirm that our core results hold (see Table A5).

${ }^{33}$ To avoid a tautological correlation, this count only considers organizations other than the one corresponding to a given observation in the dataset.

${ }^{34}$ Indeed, the logged number of co-creations is not a significant predictor of organizational types.
} 
predicts the choice of TGIs, but the result loses robustness upon inclusion of fixed effects. Issue area complexity does not seem to matter, possibly because it is already explained by period dummies. Further, a smaller number of states facilitates cooperation through TGIs as opposed to formal IGOs $(\mathrm{p}<0.01)$. Overall, functionalism receives mixed support, with some of its variables receiving robust support across different model specifications.

A similar picture emerges for power-oriented accounts. Consistent with expectations, a more unequal power distribution adversely affects the odds of institutionalized cooperation $(\mathrm{p}<0.01)$. The presence of powerful countries as such tends to have a similar effect. As to TGI design, the presence of powerful countries promotes TGI designs, but part of the effect can be explained away by fixed effects so that power remains marginally significant in the last model. Power differences across member states do not have a significant effect on the TGI design choice.

Domestic politics receives relatively less support across the models. In the creation stage, none of the polity variables is statistically significant, although their estimated directions are consistent with theoretical expectations. In the design stage, more democratic groups of states prefer to design TGIs. The effects of regime type differences are statistically insignificant.

The contextual design view receives robust support. Consistent with expectations, states are less likely to create a new organization if a previous organization fulfills similar functions. When controlling for issue area dummies, this effect is statistically significant $(p<0.05)$. In addition, states are less likely to design a TGI to the extent that the most-similar previous organization fulfills similar governance functions in the same issue area. This result is statistically significant across different models-despite a host of controls and dummies for time periods, issue areas, governance tasks, and the (logged) number of states in the system.

To examine the substantive importance of the various explanations, we calculate the effects of an increase in the relevant predictors by their respective standard deviation (SD). ${ }^{35}$ With respect to institutional creation, we find that a 1-SD increase in issue complexity reduces the likelihood of a new organization to be established by at most $13.7 \%(p<0.01)$. Conversely, a 1-SD increase in power differences predicts at most a $10.4 \%$ lower likelihood of institutional creation $(\mathrm{p}<0.01)$. Finally, a 1-SD increase in IO similarity reduces the likelihood of creation by at most $4.3 \%(\mathrm{p}<0.05)$.

With respect to institutional design, a 1-SD increase in membership reduces the TGI probability by $7.7 \%(95 \%$-CI: $2.6 \%$ to $14.0 \%)$, while the same increase in preference heterogeneity increases this probability by $7.9 \%$ (95\%-CI: $0.7 \%$ to $15.2 \%)$. Furthermore, a $1-$ SD increase in power prevalence is associated with at most a $14.1 \%$ higher likelihood of TGIs (95\%-CI: $3.7 \%$ to $24.6 \%$ ), while a 1 -SD increase in Polity IV implies at most 5.6\% (95\%-CI: $0.2 \%$ to $11.0 \%$ ). Finally, increasing IO similarity by 1 -SD reduces the TGI probability by at most $6.9 \%$ (95\%-CI: $2.7 \%$ to $11.1 \%)$.

Overall, this suggests that for the development regime the most relevant explanations for institutional choices are issue complexity and power differentials as far as institutional

\footnotetext{
${ }^{35}$ We always interpret the highest of the coefficients to obtain an upper bound.
} 
creation is concerned. To account for the choice of TGIs, power prevalence is the most influential variable, while functionalist variables and contextual design are similarly important with somewhat lower predicted effect sizes. Average democracy is the least important explanation for the choice of TGIs.

Model diagnostics undergird the plausibility of the estimates. The goodness of fit is strong, implying that the log-likelihoods of the models are at least twice as large as a null model without any predictors. Furthermore, there is no residual correlation in the errors of the two equations, which suggests that no important joint determinants of institutional design choices were omitted. Finally, the variable SYSTEM GROWTH, which is the logged number of other organizations created in the same year, is a highly relevant predictor for the creation of a given organization $(F \geq 23)$. To the extent that it is excludable, the second-stage estimates are causally interpretable.

[Table 3 here]

\section{Robustness tests}

Beyond considering various sets of control variables in the above analysis, we further probe the robustness of our main results in the supplemental appendix and report briefly on the findings of this exercise here. First, we use an alternative operationalization of the dependent variable, which compares TGIs across all other organizations (rather than just IGOs) in the second stage. This increases the number of potential observations by 49 IIGO cases but does not otherwise affect the substantive conclusions to be drawn from the regressions (Table A1).

Second, we also test the four institutional design explanations individually. This reduces multi-collinearity and thus we can estimate the effects of some predictors more precisely. For instance, preference heterogeneity now tends to be negatively related to institutional creation, while continuing to be driving the choice of TGIs. Similarly, estimates of democracy are more precise in both stages $(\mathrm{p}<0.01)$. The same conclusion holds for the contextual design variable, which is strongly negatively significant in both stages (Table A2). Results are also robust when changing the relevant comparison group-juxtaposing TGIs against formal IGOs and informal IGOs (Table A3) — rather than just IGOs as in the previous robustness check.

Finally, we use a continuous measure of organizational structure as the dependent variable rather than organizational types. This robustness test is useful because TGIs tend to be less structured than formal IGOs, although TGIs also vary in their level of institutionalization. Note that this reverses the expected coefficient signs in the second stage. Tapping the additional variation in structure, we find that functionalism and specifically issue area complexity becomes a more salient explanation of institutional design, while the power-based explanation loses its significance in the TGI stage. With regard to domestic politics, it is now the difference across regime types that positively relates to the choice of TGIs. Finally, the contextual design results are highly significant in both stages and consistent with theoretical expectations (Table A4).

Overall, the analysis has produced some robust associations between institutional design choices and rationalist design theories. In line with functionalism, issue complexity makes 
new institutions less likely and tends to make adoption of TGI designs more likely. In addition, power differentials reduce the likelihood of new institutions, while homogenous groups of powerful states prefer TGIs to govern development cooperation. In line with contextual design, higher degrees of similarity with the organizational field reduce the appetite for new institutions but increase the chances of states choosing a TGI design. To cast light on the underlying mechanisms, we now present evidence from a qualitative case study.

\section{Case study}

To illustrate the quantitative findings, we study the establishment of the IFCS. The statistical model predicts well both its creation and its organizational type. ${ }^{36}$ Therefore, an in-depth study of this case promises insights into the mechanism underlying contextual design and other institutional design explanations. The purpose of the case study thus is not a 'hard test' of our argument, but to demonstrate its plausibility by examining motivations of key stakeholders involved in the design choice.

\section{Organizational purpose}

The IFCS was established in 1994 as a multi-stakeholder alliance around the issue of chemical safety - "the prevention of the adverse effects [...] to humans and the environment from the production, storage, transportation, use, and disposal of chemicals." "37 Its goal was to develop international partnerships among its diverse stakeholders including national governments, IGOs, and NGOs such as public-interest associations, labor unions, industry groups, scientific bodies, and civil society representatives for the sound management of chemicals. IFCS was the only forum where any stakeholder could bring up any issue related to sound management of chemicals. Its key activities included the provision of policy guidance, the development of strategies in a coordinated manner, the fostering of understanding of issues and stakeholder positions, and the promotion of policy support. ${ }^{38}$ The day-to-day administrative work was supported by a trust fund, which also facilitated participation of developing countries and local NGOs. ${ }^{39}$ In terms of institutional structure, the Forum Sessions represented the highest decision-making organ in which all participants participated. The Forum Sessions delegated certain functions to the Forum Standing Committee, which served as conduit for the views of participant countries in their respective IFCS regions or non-governmental constituency. The Standing Committee comprised 25 IFCS participants and was supported by the Executive Secretary. ${ }^{40}$

\section{Dimensions of informality}

\footnotetext{
${ }^{36}$ The predicted probabilty of creation is $91 \%$ and the predicted probability of a TGI design is $65 \%$.

${ }^{37} \mathrm{http}: / / \mathrm{www}$. who.int/ifes/en/.

${ }^{38} \mathrm{http}: / / \mathrm{www}$.who.int/ifes/en/.

${ }^{39}$ https://www.who.int/ifcs/financing/en/.

${ }^{40}$ http://www.who.int/ifcs/standingcommittee/en/.
} 
In terms of organizational type, IFCS was a TGI as its constitutive members included states and non-state actors. Compared to other TGIs, it was relatively structured. IFCS had a secretariat, hosted at the WHO. Its terms of reference codified voting procedures, notably decision-making by consensus in the forum on all decisions. There were no provisions for monitoring, enforcement, and dispute settlement.

In terms of policy output, IFCS produced non-legally binding resolutions. Its main task was to issue reports that synthesized independent information on chemical safety, including the related implications on health, the environment, and socioeconomic development. Its aims were to "build partnerships, provide advice and guidance, make recommendations, and monitor progress." 41 IFCS had neither the mandate nor the resources to implement recommendations; rather, it relied on decentralized action by governments, for instance through the IGOs that participated in it.

\section{Historical background}

The issue of chemical safety emerged first in the developed countries when new chemicals came to the market but very few were ever evaluated for their health consequences, creating a need for risk assessment, information sharing, knowledge production, and waste management. Two factors facilitated a global regulatory response: the first was growing economic interdependence and trade in chemicals, which could only be insufficiently addressed at the national level; the second was growing public concern about the environment, which led to the establishment in the United Nations Environment Program (UNEP) at the Stockholm conference in 1972. The conference also identified chemical safety as a cross-cutting issue covering health, labor, and the environment. All sectors had a vital interest in chemicals, but operated in isolation. In 1977, WHO decided to set up an International Program on Chemical Safety (IPCS) - an inter-agency program between WHO, the International Labour Organization (ILO), and UNEP for which WHO provided the secretariat and which started operations in 1980. The main role of the program was to develop international cooperative projects to strengthen capacity, particularly in developing countries to protect human health and the environment from toxic chemicals. The tripartite nature of the program reflected the cross-sectional nature of chemicals, with implications for public health (WHO), occupational health (ILO), and environmental health (UNEP). ${ }^{42}$

Hence, in the years before IFCS was established, the key problem was that - despite existence of the IPCS - the chemical safety regime was fragmented, as individual UN entities had reverted to their own programs and paid lip service to coordination. Hence, a central agency with the mandate to address all related aspects of chemical safety and tight intergovernmental oversight was desirable. Indeed, there was a window of opportunity for an intergovernmental process when the report of the Brundtland Commission helped the issue break though high on the agenda of politicians before the upcoming UN Conference on the Environment (UNCED) in Rio de Janeiro in June 1992. To advance this agenda, the WHO environmental health division organized a meeting of experts to discuss draft proposals for an Intergovernmental

\footnotetext{
${ }^{41}$ http://www.who.int/ifcs/page2/en/.

42 Interview \#1.
} 
Mechanism for Chemical Risk Assessment and Management (IMCRAM) in London in December 1992. ${ }^{43}$

The proposed solution entailed an IGO covering all aspects of chemical management. This intergovernmental mechanism would produce legally-binding output and would be supported by a technical secretariat - essentially the existing IPCS at WHO, but with expanded functions and an associated budget. However, the institutional design that was eventually adopted differed from the IMCRAM proposal. In 1994, IFCS was established at a meeting hosted by the government of Sweden convening 114 countries, the executive heads of UNEP, ILO, and WHO, and non-governmental organizations. IFCS was a rather loose forum, where issues were debated but its resolutions remained non-legally binding. Further, IFCS did not have a technical secretariat, in the form of an expanded IPCS. However, the IFCS did follow the spirit of the IMCRAM proposal to incorporate a broad range of stakeholders in a transparent process of debate on a wide range of issues. ${ }^{44}$ Throughout its lifetime, IFCS developed institutional sub-structures to respond to ad-hoc needs, for example through regional groups, thematic working groups, and so-called 'IFCS champions'-informal networks of participants tasked with the role of increasing awareness and promoting action related to the IFCS agenda. ${ }^{45}$

IFCS proved instrumental for the creation of at least two UNEP conventions and other legally-binding agreements related to chemicals. ${ }^{46}$ For instance, IFCS facilitated the Stockholm convention on Persistent Organic Pollutants (POPs), signed in 2001. The convention originated in a Canadian initiative in the UNEP General Council, which then asked IFCS to pursue the issue further in a multi-stakeholder approach. In 1998, IFCS held two back-to-back meetings, one with experts on POPs putting together a background document, and another one with a designated expert working group comprising national governments, regional organizations, and industry groups to discuss a potential framework for a convention. The resulting proposal was sent back to the UNEP General Council, which accepted it in its basic form, leading to the Stockholm convention. ${ }^{47}$ A similar division of labor occurred in the realm of the Minamata convention on mercury, for which IFCS provided a forum for discussion. Outside the remit of UNEP, the Globally Harmonized System for Classification and Labeling (GHS) provides another example. ${ }^{48}$

\footnotetext{
${ }^{43}$ UNEP/IPCS/IMCRAM/exp/4. The proposal text was incorporated into the text for Chapter 19 of the Agenda 21 (the resolution adopted at the Rio conference) dedicated to sound management of chemicals (although the issue of chemical waste was a separate chapter).

${ }^{44}$ Indeed, unlike the existing forums, IFCS had the remarkable feature of allowing all forum stakeholders to raise any issue related to chemical safety at any time.

${ }^{45} \mathrm{http}: / / w w w . w h o . i n t /$ ifcs/champions/en/.

${ }^{46}$ Interview \#1.

${ }^{47}$ Interview \#2.

${ }^{48}$ States have been seeking internationally agreed-upon standards on hazardous materials and labeling schemes at the Rio Earth summit, but progress was slow, presumably because developing countries lacked the capacity to implement the standards. IFCS helped improve knowledge of health hazards related to chemicals and facilitated GHF training for developing countries through UNITAR (Interview \#3).
} 
Eventually, IFCS ceased to have an independent existence. In 2008, at its Sixth Forum Sessions in Dakar, it was decided to integrate IFCS as an advisory body into the International Conference for Chemicals Management (ICCM), performing the role of gathering critical knowledge and sharing relevant expertise for regulating health hazards. ${ }^{49}$

\section{Illustrating theories of institutional design}

The design of IFCS as a TGI is broadly consistent with functionalism. IFCS was useful for states as it was not constrained by legal formalities, especially regarding which types of issues could be discussed in the governing body. This allowed stakeholders to identify and act upon emergent cross-cutting issues, for instance nanotechnology. Furthermore, IFCS made it easier to involve all relevant stakeholders, thus holding promise to generate the required expert information and foster consensus more quickly. In this way, IFCS proved catalytic for subsequent legally-binding conventions. However, some design features of IFCS must appear puzzling to functionalists. In particular, the technical complexity of chemical safety would have warranted an independent secretariat, which was indeed proposed but eventually not adopted.

A power-based approach can account for the lack of legal substance. Despite preference for a legally binding instrument among Nordic countries and environmental NGOs, the IMCRAM proposal was watered down following US pressure. As the most powerful stakeholder, the US asserted itself with its insistence on having no legally binding instrument and no technical secretariat financed by assessed contributions. ${ }^{50}$

Domestic politics also contributed to the design of IFCS as a TGI. On the one hand, the prevention of a legally-binding mechanism was a major win for the chemical industry, which lobbied hard against the IMCRAM proposal. ${ }^{51}$ Conversely, chemical corporations were more supportive of the UNEP-promoted legally binding conventions because these targeted specific chemicals that they did no longer use and thus compliance with these conventions was costless to them. ${ }^{52}$ On the other hand, the flexible agenda-setting approach of IFCS was welcomed especially by NGOs and developing countries. The open-endedness of the discussions allowed these actors to bring up issues salient to them and build on deliberative dynamics to promote support coalitions. IFCS also allowed non-governmental actors to provide opinions at any time, in contrast to traditional IGOs where these actors were invited to provide factual comments after all governments had spoken. Furthermore, NGOs and developing countries felt that the requirement to make decisions by consensus put them in a more equal position vis-à-vis rich countries compared to traditional IGOs. ${ }^{53}$

\footnotetext{
${ }^{49}$ Interview \#1.

${ }^{50}$ Interviews \#1, \#2, and \#3.

${ }^{51}$ Interview \#1.

52 Interview \#3.

${ }^{53}$ Interview \#2. Similarly, the IFCS website states, "[t] he IFCS provides countries the opportunity to place issues on the international agenda and emphasize special needs and concerns with respect to improving chemicals management. All participants, including developing countries and NGOs, find it a useful mechanism to bring emerging and contentious issues to the international agenda." (http://www.who.int/ifcs/page2/en/).
} 
A contextual design perspective can account for the remaining gaps in the explanation. While puzzling to functionalism, this view can explain why IFCS lacked a technical secretariat: the relevant technical expertise was already provided by the participating IGOs through their respective chemicals programs. The role of IFCS then was to bring new issues on the agenda, fostering consensus, and orchestrating policy action. It had no capacity for implementing policy resolutions but to that end relied on decentralized action.

IFCS had to be created precisely because there was no open-ended coordination forum to deal with new upcoming issues in chemical management. For instance, the UNEP conventionsdealing with specific chemicals - had strict limitations as to which issues could be brought on the agenda. The specific choice of a TGI was driven by the recognition that sound chemical management is a complex challenge that requires the involvement of multiple nongovernmental stakeholders - scientific experts, NGOs, and the chemical industry-for it to be effectively addressed. ${ }^{54}$

The IFCS case demonstrates that states are motivated by the dual desire to establish governance mechanisms that are tailored to solve specific problems and to avoid task duplication in the regime by creating new organizations. States designed IFCS so that it would perform vital roles in the chemical safety regime-bringing all relevant stakeholders from multiple sectors and multiple organizations together and galvanizing action through adhoc partnerships-while not duplicating existing functions. Especially the industrialized countries - as the ultimate donors of the organization - were adamant on avoiding duplication but conceived a need for a "think tank" to enable solutions and foster partnerships, with financing for chemical programs coming through bilateral projects and funding to WHO, UNEP, and ILO, earmarked for chemical safety. ${ }^{55}$

\section{Summary and conclusion}

The most significant trend in the recent history of the multilateral development system is the rapid growth of TGIs - partnerships between states, IGOs, and non-state actors to address global development challenges (Andonova and Levy 2003; Bull, Bøås, and McNeill 2004; Hale and Roger 2014). Dominated by Western governments, TGIs dominate the multilateral development system by their numbers alone, often directing the global policy responses in specific sub-sectors.

In view of these trends, this article took on two important tasks. First, we documented the growth of TGIs in the development regime quantitatively, drawing on the new TGIWP data that collect information on the institutional features, policy mandates, and task profiles of 559 development organizations (Westerwinter 2019c). Second, we juxtaposed four accounts for why states design cooperative endeavors as TGIs: functionalism, power-oriented theories, domestic politics, and context-sensitive design. Using the TGIWP dataset, we tested the

\footnotetext{
${ }^{54}$ Interview \#1.

${ }^{55}$ Interview \#3. For a discussion of earmarked funding, particularly through trust funds, see, e.g., Reinsberg, Michaelowa, and Eichenauer (2015).
} 
explanatory power of these four accounts under a common framework, considering that institutional design is a two-stage process involving an initial decision to create a new organization and a subsequent decision about its institutional design. We found that institutional choices can be well-explained jointly by all four design theories, while poweroriented theories, functionalism, and contextual design received most robust support across various specifications.

To further illustrate the quantitative findings, we conducted an in-depth case study of the IFCS - a TGI established in 1994 as a multi-stakeholder forum for discussing issues related to sound chemicals management and tasked with gathering critical knowledge and sharing relevant expertise for regulating health hazards. Because the statistical model predicted this case well, we found evidence for all four accounts of institutional design. The contextsensitive design view, however, proved most useful in explaining critical design choices - the multi-stakeholder nature of the organization and its lack of an independent technical secretariat - which other accounts could not explain well. In addition, the case analysis revealed that informal governance - as reflected in the flexible agenda-setting approach of the IFCS Forum Sessions-worked to empower relatively powerless actors, such as developing countries, small countries from the North, and NGOs - given their perceived greater influence compared to a hypothetical IGO solution. Informal governance can thus empower NGOs and other weaker players (Avant and Westerwinter 2016). Because others suggest that it plays into the hands of the most powerful states (Steinberg 2002; Stone 2011), future research may need to explore conditions under which either effect holds. The analysis also revealed that the democratic qualities of an international organization benefit not only NGOs but also powerful business interests, given that the non-legally binding policy output was fully in line with the latter. By reducing the cost of influence for non-government actors, democracy thus favors actors with salient interests.

Before discussing the broader implications of our article, we mention three limitations. First, since our unit of analysis is the international organization, our institutional design predictors are necessarily blunt. Results should therefore not be interpreted as a definitive test of individual theories but as an indication of their relative usefulness. Nonetheless, our qualitative case study indicated that the measures are valid, despite their level of aggregation. Second, while our methodological choices such as the selection model helped ensure internal validity, a remaining issue with the data is that they do not take interdependencies of institutions into account. Some organizations are successors of previous organizations that eventually failed, thereby violating the independence assumption in the data. While we suspect the amount of bias that such dependencies introduce to be negligible, future research should identify such cases and take them into account in the analysis. Third, another limitation is that the data do not allow for tracing dynamically evolving mandates of organizations. Future research should aim to fill this gap by collecting time-varying data on IGO mandates.

Our findings have a number of implications for the social-scientific study of international organizations. First, the tremendous growth of TGIs over the past three decades suggests that examining only IGOs would be an incomplete-if not entirely misleading-representation of current global governance structures. However, the apparent decline of IGOs in development 
cooperation does not imply that IGOs have become irrelevant. To the contrary, most development IGOs continue to perform key roles in new TGIs. Some IGOs provide essential technical inputs and implement TGI priorities, for example the WHO with respect to the Global Fund. Other IGOs perform orchestrator functions, for example the World Bank in the early phase of the Global Environment Facility (Graham and Thompson 2015). More generally, this raises new sets of questions as to which factors determine the design of interorganizational relations (Biermann and Koops 2017; Dijkstra 2017; Hanrieder 2015), notably the relationship between informal governance and the viability of IGOs. For instance, while TGIs as informal organizations may undermine the primacy of existing IGOs, the informal governance processes that they sustain may ultimately strengthen the IGOs by helping them to stay relevant in an interconnected world.

Second, a methodological consequence of the growing importance of partnership-based forms of cooperation in global governance is that analytical leverage can be gained by capturing a regime-level perspective, which studies the interactions of various organizations working on a given issue (Biermann and Koops 2017; Gehring and Oberthür 2009; Gehring and Faude 2014). States do not design new institutions in a vacuum but with a view to shape the entire regime (Henning 2017); defining features of a regime complex thus are the multiplicity of institutions, maintained by distinct forums with participation of different actors, and a relative lack of hierarchy among these institutions (Alter and Meunier 2009; Oberthür and Stokke 2011; Raustiala and Victor 2004). A regime-level perspective on institutional design would privilege inferential network analysis approaches that are able to take spatial dependencies into account (Cranmer et al. 2017; Stadtfeld, Hollway, and Block 2017; Wang, Pattison, and Robins 2013). In the area of global governance, however, research that uses such methods is only in its infancy (Dietrich, Reinsberg, and Steinwand 2018; Westerwinter 2019b).

Third, in addition to spatial interdependence, temporal dependence in international design is another key theme of our article. The rise of TGIs has implications for theories of institutional design (Copelovitch and Putnam 2014; Jupille, Mattli, and Snidal 2013; Koremenos, Lipson, and Snidal 2001; Rixen and Viola 2016). Consider the institutional design theory by Jupille, Mattli, and Snidal (2013), who conceive institutional design as a multi-step decision-making process in which states first screen the set of existing organizations to identify one they can use (or select one from several organizations); change an existing organization if no previous one meets their new demands; or, failing that, create a new organization, which is considered the most risky and most costly option and therefore rarely chosen. While this framework is analytically useful, it assumes that new organizations can only take the form of IGOs; but states can also design new TGIs, which can upset the whole decision-making sequence, depending on the costs of alternative institutional choices. Specifically, creating a TGI is less risky and less costly than creating an IGO; it may be even cheaper than changing an existing IGO. Thus, while the model proposed by Jupille, Mattli, and Snidal (2013) is analytically useful, their decision sequence ends at a point where important variation occurs, i.e. the choice of alternative forms of institutionalized cooperation that are different from IGOs. Exploring this interesting variation theoretically and empirically along and beyond their decision sequence is an important task for future research. 
Fourth, the rise of TGIs also prompts reconsidering the debate on fragmentation as one of the purported perils of fast-growing global governance regimes (Abbott, Green, and Keohane 2016; Acharya 2016a; Barnett, Pevehouse, and Raustiala 2016). Examining drivers of fragmentation, studies point to the growing number of actors and their growing diversity, including rising powers, private philanthropists, and IGO bureaucrats (Finnemore 2014; Johnson 2014; Reisen 2010). Whether or not fragmentation adversely affects effectiveness is a yet unresolved issue. Critics argue that fragmentation undermines the effectiveness of regimes to solve global problems; advocates of institutional plurality emphasize the merits of creativity (Acharya 2016b; De Búrca, Keohane, and Sabel 2014; Henning 2017). While systematic analysis of TGI effectiveness is an issue for future research, the present article cautions against premature conclusions. Often vilified as "talking shops," TGIs can be critical for the further development of the overall regime. For example, while the informal nature of IFCS might be seen as a major weakness, it proved instrumental for facilitating legallybinding commitments in related venues.

Finally, the rise of TGIs prompts debates about whether the state has lost its role in global politics at the expense of private actors (Avant, Finnemore, and Sell 2010; Büthe 2004; Hall and Biersteker 2002; Kahler and Lake 2003). Our analysis showed that states remain key actors but no longer are the only actors in institutional design. In the IFCS case, states controlled the organizational design decisions, as they watered down the IMCRAM proposal put forward by IGO bureaucrats. As others have shown, bureaucratic influence over organizational design thus is limited to cases where states have no salient interests; where they lack expertise; or where they are late to the process (Johnson 2014; Johnson and Urpelainen 2014; Seddon 2017). As a result of an increasingly crowded multilateral development system, however, states are ever less able to control the dynamic implications of TGI formation. Once created, TGIs push forward new issues, as non-state actors have great say in them by design. States thus risk being entrapped into escalating commitments. These dynamics would again be a fascinating area for future research beyond individual case studies. 


\section{References}

Abbott, Kenneth W, Philipp Genschel, Duncan Snidal, and Bernhard Zangl. 2015. "Orchestrating Global Governance: From Empirical Findings to Theoretical Implications.” In International Organizations as Orchestrators, eds. Kenneth W Abbott, Philipp Genschel, Duncan Snidal, and Bernhard Zangl. Cambridge: Cambridge University Press, 3-36.

Abbott, Kenneth W, Jessica F. Green, and Robert O Keohane. 2016. "Organizational Ecology and Institutional Change in Global Governance." International Organization 70(2): 24777.

Abbott, Kenneth W, and Thomas N Hale. 2014. "Orchestrating Global Solutions Networks: A Guide for Organizational Entrepreneurs.” Innovations 9(1-2): 195-212.

Abbott, Kenneth W, and Duncan Snidal. 1998. "Why States Act through Formal International Organizations." Journal of Conflict Resolution 42(1): 3-32.

2000. "Hard and Soft Law in International Governance." International Organization 54(3): 421-156.

Acharya, Amitav. 2016a. "The Future of Global Governance: Fragmentation May Be Inevitable and Creative." Global Governance 22(4): 453-60.

- 2016b. Why Govern? Rethinking Demand and Progress in Global Governance. Cambridge: Cambridge University Press.

Alexandroff, Alan S, and Andrew F Cooper. 2010. Rising States, Rising Institutions: Challenges for Global Governance. Brookings Institution Press.

Allee, Todd, and Manfred Elsig. 2014. "Why Do Some International Institutions Contain Strong Dispute Settlement Provisions? Evidence from Preferential Trade Agreements." In Annual Conference on the Political Economy of International Organizations, Princeton University January 16-18.

Alter, Karen J., and Sophie Meunier. 2009. “The Politics of International Regime Complexity." Perspectives on Politics 7(1): 13-24.

Andonova, Liliana B. 2010. "Public-Private Partnerships for the Earth: Politics and Patterns of Hybrid Authority in the Multilateral System." Global Environmental Politics 10(2): $25-53$.

. 2014. "Boomerangs to Partnerships? Explaining State Participation in Transnational Partnerships for Sustainability." Comparative Political Studies 47(3): 481-515.

Andonova, Liliana B., Thomas N. Hale, and Charles B. Roger. 2017. "National Policy and Transnational Governance of Climate Change: Substitutes or Complements?" International Studies Quarterly 61(2): 253-68.

Andonova, Liliana B., and Marc A. Levy. 2003. "Franchising Global Governance: Making Sense of the Johannesburg Type II Partnerships." In Yearbook of International CoOperation on Environment and Development, , 19-32.

Avant, Deborah D, Martha Finnemore, and Susan K Sell. 2010. Who Governs the Globe? New York: Cambridge University Press. 
Avant, Deborah D, and Oliver Westerwinter. 2016. The New Power Politics: Networks and Transnational Security Governance. Oxford: Oxford University Press.

Axelrod, Robert. 1984. The Evolution of Cooperation. New York: Basic Books.

Bäckstrand, Karin. 2006. "Democratizing Global Environmental Governance? Stakeholder Democracy after the World Summit on Sustainable Development." European Journal of International Relations 12(4): 467-98.

Bailey, Michael A, Anton Strezhnev, and Erik Voeten. 2015. "Estimating Dynamic State Preferences from United Nations Voting Data." Journal of Conflict Resolution 61(2): 430-56.

Barnett, Michael N, Jon C Pevehouse, and Kal Raustiala. 2016. "The Future of Global Governance:" In Draft Paper for the Workshop "The Future of Global Governance”.

Bayer, Patrick, Christopher Marcoux, and Johannes Urpelainen. 2015. "When International Organizations Bargain: Evidence from the Global Environment Facility." Journal of Conflict Resolution 59(6): 1074-1100.

Benvenisti, Eyal. 2006. "“Coalitions of the Willing' and the Evolution of Informal International Law." Tel Aviv University Legal Working Paper Series: 31.

Berliner, Daniel, and Aseem Prakash. 2015. "'Bluewashing' the Firm? Voluntary Regulations, Program Design, and Member Compliance with the United Nations Global Compact." Political Studies Journal 43(1): 115-38.

Bernstein, Steven. 2013. "Rio+ 20: Sustainable Development in a Time of Multilateral Decline." Global Environmental Politics 13(4): 12-21.

Best, Jacqueline. 2012. "Ambiguity and Uncertainty in International Organizations: A History of Debating IMF Conditionality.” International Studies Quarterly 56(4): 674-88.

Biermann, Frank. 2017. A World Environment Organization: Solution or Threat for Effective International Environmental Governance? London: Routledge.

Biermann, Frank, Philipp Pattberg, Harro Van Asselt, and Fariborz Zelli. 2009. "The Fragmentation of Global Governance Architectures: A Framework for Analysis." Global Environmental Politics 9(4): 14-40.

Biermann, Rafael, and Joachim A Koops. 2017. The Palgrave Handbook of InterOrganizational Relations in World Politics. London: Palgrave Macmillan.

Blanchfield, Lisa. 2008. "United Nations Reform: U.S. Policy and International Perspectives.” Congressional Research Service RL33848.

Bulkeley, Harriet et al. 2014. Transnational Climate Change Governance. Cambridge: Cambridge University Press.

Bull, Benedicte, Morten Bøås, and Desmond McNeill. 2004. "Private Sector Influence in the Multilateral System: A Changing Structure of World Governance?" Global Governance 10(4): 481-98.

De Búrca, Gráinne, Robert O Keohane, and Charles Sabel. 2014. "Global Experimentalist Governance.” British Journal of Political Science 44(3): 477-86. 
Biermann, Frank, Philipp Pattberg, Harro van Asselt, and Fariborz Zelli. 2009. "The Fragmentation of Global Governance Architectures: A Framework for Analysis. " Global Environmental Politics 9(4): 14-40.

Busch, Marc L. 2007. "Overlapping Institutions, Forum Shopping, and Dispute Settlement in International Trade.” International Organization 61(4): 735-61.

Büthe, Tim. 2004. "Governance through Private Authority? Non-State Actors in World Politics.” Journal of International Affairs 58(1): 281-90.

Büthe, Tim, and Cindy Cheng. 2013. "International Development Aid.” In Handbook of Global Economic Governance, eds. Manuela Moschella and Catherine E Weaver, 32242.

Clarke, Lisa. 2014. Public-Private Partnerships and Responsibility Under International Law. London: Routledge.

Colgan, Jeff D., Robert O Keohane, and Thijs van de Graaf. 2012. "Punctuated Equilibrium in the Energy Regime Complex.” Review of International Organizations 7(2): 117-43.

Cooley, Alexander, and James Ron. 2002. "The NGO Scramble: Organizational Insecurity and the Political Economy of Transnational Action." International Security 27(1): 5-39.

Copelovitch, Mark S, and Tonya L Putnam. 2014. "Design in Context: Existing International Agreements and New Cooperation.” International Organization 68(2): 471-93.

Cranmer, Skyler J., Philip Leifeld, Scott D. McClurg, and Meredith Rolfe. 2017. "Navigating the Range of Statistical Tools for Inferential Network Analysis." American Journal of Political Science 61(1): 237-51.

Dietrich, Simone, Bernhard Reinsberg, and Martin C. Steinwand. 2018. Network Governnace in International Organizations: Evidence from World Bank Trust Funds. Glasgow: University of Glasgow.

Dijkstra, Hylke. 2017. "The Rational Design of Relations Between Intergovernmental Organizations." In Palgrave Handbook of Inter-Organizational Relations in World Politics, eds. Joachim Koops and Rafael Biermann. London: Palgrave MacMillan, 97112.

DiMaggio, Paul J, and Walter W Powell. 1991. "Introduction." The New Institutionalism in Organizational Analysis: 1-40.

Dingwerth, Klaus, and Philipp Pattberg. 2009. "World Politics and Organizational Fields: The Case of Transnational Sustainability Governance." European Journal of International Relations 15(4): 707-43.

Dingwerth, Klaus, Henning Schmidtke, and Tobias Weise. 2011. "Speaking Democracy: Why International Organizations Adopt a Democratic Rhetoric." In Legitimacy and Legitimation in Global Governance, eds. Jonas Tallberg and Michael Zürn.

Drezner, Daniel W. 2009. "The Power and Peril of International Regime Complexity." Perspectives on Politics 7(1): 65-70.

Duffield, John S. 2003. "The Limits of \&quot;Rational Design\&quot;” International Organization 57(2): 411-30. 
Dür, Andreas, Leonardo Baccini, and Manfred Elsig. 2013. "The Design of International Trade Agreements: Introducing a New Dataset." Review of International Organizations 9(3): 353-75.

Eichenauer, Vera Z., and Bernhard Reinsberg. 2017. "What Determines Earmarked Funding to International Development Organizations? Evidence from the New Multi-Bi Aid Data." Review of International Organizations 12(2): 171-97.

Eilstrup-Sangiovanni, Mette. 2015. "Varieties of Cooperation: Government Networks in International Security." In Networked Politics, ed. Miles Kahler. Ithaca and London: Cornell University Press, 193-227.

Elsig, Manfred, and Franck Amalric. 2008. "Business and Public-Private Partnerships for Sustainability: Beyond Corporate Social Responsibility?” Global Society 22(3): 387404.

Falkner, Robert. 2016. "The Paris Agreement and the New Logic of International Climate Politics." International Affairs 92(5): 1107-25.

Farrell, Henry, and Abraham L. Newman. 2014. "Domestic Institutions beyond the NationState: Charting the New Interdependence Approach.” World Politics 66(2): 331-63.

Favotto, Alvise, and Kelly Kollman. 2018. (Corporate) Responsibility for What? The Uneven Embedding of Sustainability Issues in Global Markets. Glasgow: University of Glasgow.

Fidler, David P. 2016. "Health." In Why Govern? Rethinking Demand and Progress in Global Governance, ed. Amitav Acharya. Cambridge: Cambridge University Press, 230-251.

Finnemore, Martha. 2014. "Dynamics of Global Governance: Building on What We Know." International Studies Quarterly 58(1): 221-24.

Fioretos, Orfeo. 2011. "Historical Institutionalism in International Relations." International Organization 65(2): 367-99.

_. 2017. "Institutions and Time in International Relations." In International Politics and Institutions in Time, Oxford: Oxford University Press, 3-36.

Florini, Ann. 2011. “The International Energy Agency in Global Energy Governance.” Global Policy 2(1): 40-50.

Gehring, T., and S. Oberthur. 2009. "The Causal Mechanisms of Interaction between International Institutions.” European Journal of International Relations 15(1): 125-56.

Gehring, Thomas, and Benjamin Faude. 2014. "A Theory of Emerging Order within Institutional Complexes: How Competition among Regulatory International Institutions Leads to Institutional Adaptation and Division of Labor." Review of International Organizations 9(4): 471-98.

Gilligan, Michael J. 2004. "Is There a Broader-Deeper Trade-off in International Multilateral Agreements?" International Organization 58(3): 459-84.

Gilpin, Robert. 1981. War and Change in World Politics. Cambridge: Cambridge University Press.

Gould, Erica R. 2017. "What Consensus? Explaining the Rise of Consensus Decision-Making in International Organizations." Paper presented the Political Economy of International 
Organizations conference, Berne, January 7-9.

Grabel, Ilene. 2011. "Not Your Grandfather's IMF: Global Crisis, Productive Incoherence, and Developmental Policy Space." Cambridge Journal of Economics 35(5), 805-830.

Graham, Erin R. 2017. "The Promise and Pitfalls of Assembled Institutions: Lessons from the Global Environment Facility and UNAIDS.” Global Policy 8(1): 52-61.

Graham, Erin R, and Alexander Thompson. 2016. "Efficient Orchestration? The Global Environment Facility in the Governance of Climate Adaptation." In International Organizations as Orchestrators, eds. Kenneth W. Abbott, Philipp Genschel, Duncan Snidal, and Bernhard Zangl. Cambridge: Cambridge University Press, 114-138.

Grieco, Joseph M. 1988. "Anarchy and the Limits of Cooperation: A Realist Critique of the Newest Liberal Institutionalism.” International Organization 42(3): 485-507.

Gruber, Lloyd. 2000. Ruling the World: Power Politics and the Rise of Supranational Institutions. Princeton (NJ): Princeton University Press.

Haas, Ernst B. 1964. Beyond the Nation State: Functionalism and International Integration. Palo Alto.

Hale, Thomas, David Held, and Kevin Young. 2013. "Gridlock: From Self-Reinforcing Interdependence to Second-Order Cooperation Problems." Global Policy 4(3): 223-35.

Hale, Thomas, and Charles Roger. 2014. "Orchestration and Transnational Climate Governance." Review of International Organizations 9(1): 59-82.

Hall, Rodney B, and Thomas J Biersteker. 2002. "The Emergence of Private Authority in Global Governance." Cambridge: Cambridge University Press.

Hanrieder, Tine. 2015. "WHO Orchestrates? Coping with Competitors in Global Health." In International Organizations as Orchestrators, eds. Kenneth W. Abbott, Philipp Genschel, Duncan Snidal, and Bernhard Zangl. Cambridge: Cambridge University Press, $191-213$.

Heckman, James J. 1976. "The Common Structure of Statistical Models of Truncation, Sample Selection and Limited Dependent Variables and a Simple Estimator for Such Models." In Annals of Economic and Social Measurement, ed. National Bureau of Economic Research, 475-92.

Helfer, Laurence R. 2004. "Regime Shifting: The TRIPS Agreement and New Dynamics of International Intellectual Property Lawmaking." The Yale Journal of International Law 29(1): 1-83.

Henning, C Randall. 2017. Tangled Governance: International Regime Complexity, the Troika, and the Euro Crisis. Cambridge: Cambridge University Press.

Hoffmann, Matthew J. 2011. Climate Governance at the Crossroads: Experimenting with a Global Response after Kyoto. Oxford: Oxford University Press.

Honaker, James, Gary King, and Matthew Blackwell. 2011. “AMELIA II: A Program for Missing Data." Journal of Statistical Software 45(7): 1-54.

Hooghe, Liesbet, and Gary Marks. 2015. "Delegation and Pooling in International Organizations." Review of International Organizations 10(3): 305-28. 
Humphrey, Chris. 2015. "Will the Asian Infrastructure Investment Bank's Development Effectiveness Be a Victim of China's Diplomatic Success?" In Multilateral Development Banks in the 21st Century: Three Perspectives on China and the Asian Infrastructure Investment Bank, eds. Chris Humphrey et al. London: Overseas Development Institute, $3-7$.

Ikenberry, G John. 2001. After Victory: Institutions, Strategic Restraint, and the Rebuilding of Order after Major Wars. Princeton (NJ): Princeton University Press.

Ingram, Paul, and Magnus Thor Torfason. 2010. "Organizing the In-between: The Population Dynamics of Network-Weaving Organizations in the Global Interstate Network." Administrative Science Quarterly 55(4): 577-605.

Johnson, Tana. 2014. Organizational Progeny: Why Governments Are Losing Control over the Proliferating Structures of Global Governance. Oxford: Oxford University Press.

Johnson, Tana, and Johannes Urpelainen. 2014. "International Bureaucrats and the Formation of Intergovernmental Organizations: Institutional Design Discretion Sweetens the Pot." International Organization 68(1): 177-209.

Jojarth, Christine. 2009. Crime, War, and Global Trafficking: Designing International Cooperation. Cambridge: Cambridge University Press.

Jupille, Joseph, Walter Mattli, and Duncan Snidal. 2013. International Institutional Choice: Cooperation, Alternatives, and Strategies. Cambridge: Cambridge University Press.

Kahler, Miles. 1992. "Multilateralism with Small and Large Numbers.” International Organization 46(3): 681-708.

2013. "Rising Powers and Global Governance: Negotiating Change in a Resilient Status Quo.” International Affairs 89(3): 711-29.

- 2016. "Complex Governance and the New Interdependence Approach (NIA)." Review of International Political Economy 23(5): 825-39.

Kahler, Miles, and David A Lake. 2003. Governance in a Global Economy: Political Authority in Transition. Princeton (NJ): Princeton University Press.

Kaya, Ayse. 2015. Power and Global Economic Institutions. Cambridge: Cambridge University Press.

Kell, Georg. 2013. "12 Years Later: Reflections on the Growth of the UN Global Compact." Business \& Society 52(1): 31-52.

Keohane, Robert O. 1980. "The Theory of Hegemonic Stability and Changes in International Economic Regimes, 1967-1977.” In Change in the International System, eds. Ole R Holsti, Randolph M Siverson, and Alexander L George. Boulder: Westview Press, 13162.

1984. After Hegemony: Cooperation and Discord in the World Political Economy. Princeton: Princeton University Press.

Keohane, Robert O, and Joseph S Nye. 1977. Power and Interdependence: World Politics in Transition. New York: Longman.

Kharas, Homi. 2007. Trends and Issues in Development Aid. Washington D.C. 
Kindleberger, Charles P. 1973. The World in Depression, 1929-39. Berkeley: University of California Press.

Koremenos, Barbara. 2008. "When, What, and Why Do States Choose to Delegate?" Law and Contemporary Problems 71(2003): 151-92.

. 2013. "What's Left out and Why? Informal Provisions in Formal International Law." Review of International Organizations 8(2): 137-62.

- 2016. The Continent of International Law: Explaining Agreement Design. Cambridge: Cambridge University Press.

Koremenos, Barbara, and Timm Betz. 2013. "The Design of Dispute Settlement Procedures in International Agreements." Interdisciplinary Perspectives on International Law and International Relations: The State of the Art, eds. JL Dunoff and MA Pollack, Cambridge: Cambridge University Press, 371-93.

Koremenos, Barbara, Charles Lipson, and Duncan Snidal. 2001. "The Rational Design of International Institutions.” International Organization 55(4): 761-99.

Krasner, Stephen D. 1991. "Global Communications and National Power: Life on the Pareto Frontier." World Politics 43(April): 336-66.

Lieberman, Evan S. 2005. "Nested Analysis as a Mixed-Method Strategy for Comparative Research." American Political Science Review 99(3): 435-52.

Lipson, Charles. 1991. "Why Are Some International Agreements Informal?” International Organization 45(4): 495-538.

Manning, Richard. 2014. "The Multilateral Aid System: An Assessment Following the Major Replenishments of 2013." WIDER Working Paper No. 110.

Mansfield, Edward D, and Jon C Pevehouse. 2012. "Democratization and the Varieties of International Organizations.” Journal of Conflict Resolution 52(2): 269-94.

Marah, Kaifala. 2015. "The International Dialogue on Peacebuilding and Statebuilding." In Development Cooperation Report 2015: Making Partnerships Effective Coalitions for Action., Paris: Organization for Economic Cooperation and Development.

Marshall, M, Keith Jaggers, and T R Gurr. 2010. "Polity IV Project: Political Regime Characteristics and Transitions 1800-2010: Polity Level 2004-2008."

Mearsheimer, John J. 1994. "The False Promise of International Institutions.” International Security 19(3): 5-49.

Michaelowa, Katharina, and Axel Michaelowa. 2017. "Transnational Climate Governance Initiatives: Designed for Effective Climate Change Mitigation?" International Interactions 43(1): 129-55.

Michaelowa, Katharina, Bernhard Reinsberg, and Christina Schneider. 2018. "The Politics of Delegation in the European Union." International Studies Quarterly, doi: 10.1093/isq/sqy034.

Morse, Julia C., and Robert O. Keohane. 2014. "Contested Multilateralism." Review of International Organizations 9(4): 385-412. 
Moschella, Manuela. 2011. "Lagged Learning and the Response to Equilibrium Shock: The Global Financial Crisis and IMF Surveillance.” Journal of Public Policy 31(2): 121-41.

Oberthür, Sebastian, and Olav S Stokke. 2011. Managing Institutional Complexity: Regime Interplay and Global Environmental Change. Cambridge, MA: MIT Press.

OECD. 2004. "Utstein Study Follow-up: Two Concept Papers.” In DAC Network on Development Evalution Meeting. Paris. 9-10 November, Organization for Economic Cooperation and Development.

Panneels, Kris, and Guy Beringhs. 2005. "Towards a Redesign of the UN Development Architecture." Discussion Paper DCD/DAC/RD(2005)17/RD6.

Pattberg, Philipp, Frank Biermann, Sander Chan, and Aysem Mert. 2012. Public-Private Partnerships for Sustainable Development. Emergence, Influence and Legitimacy. Cheltenham: Edward Elgar.

Pevehouse, Jon C, Timothy McManus, Roseanne Nordstrom, Megan Shannon, and Monica Widmann. 2015. Codebook for Correlates of War 3 International Governmental Organizations Data Set Version 3.0. Wisconsin.

Pevehouse, Jon C, Timothy Nordstrom, and Kevin Warnke. 2004. "The COW-2 International Organizations Dataset Version 2.0." Conflict Management and Peace Science 21(2): 101-119.

Putnam, Robert D. 1988. "Diplomacy and Domestic Politics: The Logic of Two-Level Games" eds. Peter B Evans, Harold K Jacobson, and Robert D Putnam. International Organization 42(3): 427-60.

Raustiala, Kal. 2005. "Form and Substance in International Agreements." American Journal of International Law 99(3): 581-614.

Raustiala, Kal, and David G Victor. 2004. "The Regime Complex for Plant Genetic Resources.” International Organization 58(2): 277-309.

Reinsberg, Bernhard. 2016. "The Implications of Multi-Bi Financing on Multilateral Agencies: The Example of the World Bank." In The Fragmentation of Aid: Concepts, Measurements and Implications for Development Cooperation, eds. T Mahn, M Negre, and S Klingebiel. Basingstoke: Palgrave Macmillan, 185-98.

. 2017. "Trust Funds as a Lever of Influence at International Development Organizations." Global Policy 8(5): 85-95.

Reinsberg, Bernhard, Katharina Michaelowa, and Vera Z Eichenauer. 2015. "The Rise of Multi-Bi Aid and the Proliferation of Trust Funds." In Handbook on the Economics of Foreign Aid, eds. Mak Arvin and Byron L Lew. Northhampton: Edward Elgar, 527-54.

Reinsberg, Bernhard, Katharina Michaelowa, and Stephen Knack. 2017. " Which Donors, Which Funds? Bilateral Donors' Choice of Multilateral Funds at the World Bank." International Organization 71(4): 767-802.

Reisen, Helmut. 2010. "The Multilateral Donor Non-System: Towards Accountability and Efficient Role Assignment.” Economics e-Journal 4(5): 1-22.

Remmer, Karen L. 2002. “Does Democracy Promote Interstate Cooperation? Lessons from 
the Mercosur Region.” International Studies Quarterly 42(1): 25-51.

Rixen, Thomas, and Lora A Viola. 2016. "Historical Institutionalism and International Relations: Explaining Institutional Development in World Politics." In Historical Institutionalism and International Relations, eds. Thomas Rixen, Lora A Viola, and Michael Zürn. Oxford: Oxford University Press, 1-34.

Rodrik, Dani. 1995. Why Is There Multilateral Lending? NBER Working Paper No. 5160.

Rosendorff, B Peter, and Helen V Milner. 2001. "The Optimal Design of International Trade Institutions: Uncertainty and Escape Clauses.” International Organization 55(4): 829_ 57.

Rubin, D B. 1987. "Multiple Imputation for Nonresponse in Surveys.” New York: John Wiley \& Sons.

Sartori, Anne. 2003. "An Estimator for Some Binary-Outcome Selection Models without Exclusion Restrictions." Political Analysis 11(2): 111-38.

Seddon, Jack. 2017. "History Matters: How International Regimes Become Entrenched and Why We Suffer for It." International Studies Quarterly 61(2): 455-470.

Simmons, Beth A. 2000. "International Law and State Behavior: Commitment and Compliance in International Monetary Affairs." American Political Science Review 94(4): 819-35.

Slaughter, Anne-Marie. 2004. A New World Order: Government Networks and the Disaggregated State. Princeton (NJ): Princeton University Press.

Stadtfeld, Christoph, James Hollway, and Per Block. 2017. "Dynamic Network Actor Models: Investigating Coordination Ties through Time." Sociological Methodology 47(1): 1-40.

Steinberg, Richard H. 2002. "In the Shadow of Law or Power? Consensus-Based Bargaining and Outcomes in the GATT/WTO." International Organization 56(2): 339-74.

Stone, Randall W. 2011. Controlling Institutions: International Organizations and the Global Economy. Cambridge: Cambride University Press.

2013. "Informal Governance in International Organizations: Introduction to the Special Issue.” Review of International Organizations 8(2): 121-36.

Tallberg, Jonas, Thomas Sommerer, and Theresa Squatrito. 2016. "Democratic Memberships in International Organizations: Sources of Institutional Design." Review of International Organizations 11(1): 59-87.

Thérien, Jean-Philippe, and Vincent Pouliot. 2006. "The Global Compact: Shifting the Politics of International Development?" Global Governance 12(1): 55-75.

Thompson, Alexander. 2009. "The Rational Enforcement of International Law: Solving the Sanctioners' Dilemma.” International Theory 1(2): 307.

Vabulas, Felicity, and Duncan Snidal. 2013. “Organization without Delegation: Informal Intergovernmental Organizations (IIGOs) and the Spectrum of Intergovernmental Arrangements." Review of International Organizations 8(2): 193-220.

Verdier, Daniel. 2015. “The Dilemma of Informal Governance with Outside Option as 
Solution." International Theory 7(1): 195-229.

Voeten, Erik. 2001. "Outside Options and the Logic of Security Council Action.” American Political Science Review 95(4): 845-58.

Wang, Peng, Philippa Pattison, and Garry Robins. 2013. "Exponential Random Graph Model Specifications for Bipartite Networks-A Dependence Hierarchy." Social Networks 35(2): 211-22.

Webb, Michael C, and Stephen D Krasner. 1989. "Hegemonic Stability Theory: An Empirical Assessment." Review of International Studies 15(2): 183-98.

Westerwinter, Oliver. 2019a. Contextual Design: Existing International Institutions and New Transnational Governance. St. Gallen.

. 2019b. "The Evolution of Transnational Governance Overlaps: A Network Approach.” In Transnational Business Governance Interactions: Advancing Marginalized Actors and Enhancing Regulatory Quality, eds. Stepan Wood et al. Cheltenham: Edward Elgar.

-2019c. Transnational Public-Private Governance Initiatives in World Politics: Introducing a New Dataset. St. Gallen.

. 2019d. Who Joins? Democracy and State Participation in Transnational Governance. St. Gallen.

Westerwinter, Oliver, Kenneth W Abbott, and Thomas J Biersteker. 2019. Informal Governance in World Politics. St. Gallen.

World Bank. 2008. Aid Architecture: An Overview of the Main Trends in Official Development Assistance. Washington D.C.

_. 2015. "World Development Indicators." http://data.worldbank.org/. 


\section{Figures and tables}

Figure 1: Institutional creation in the multilateral development architecture.

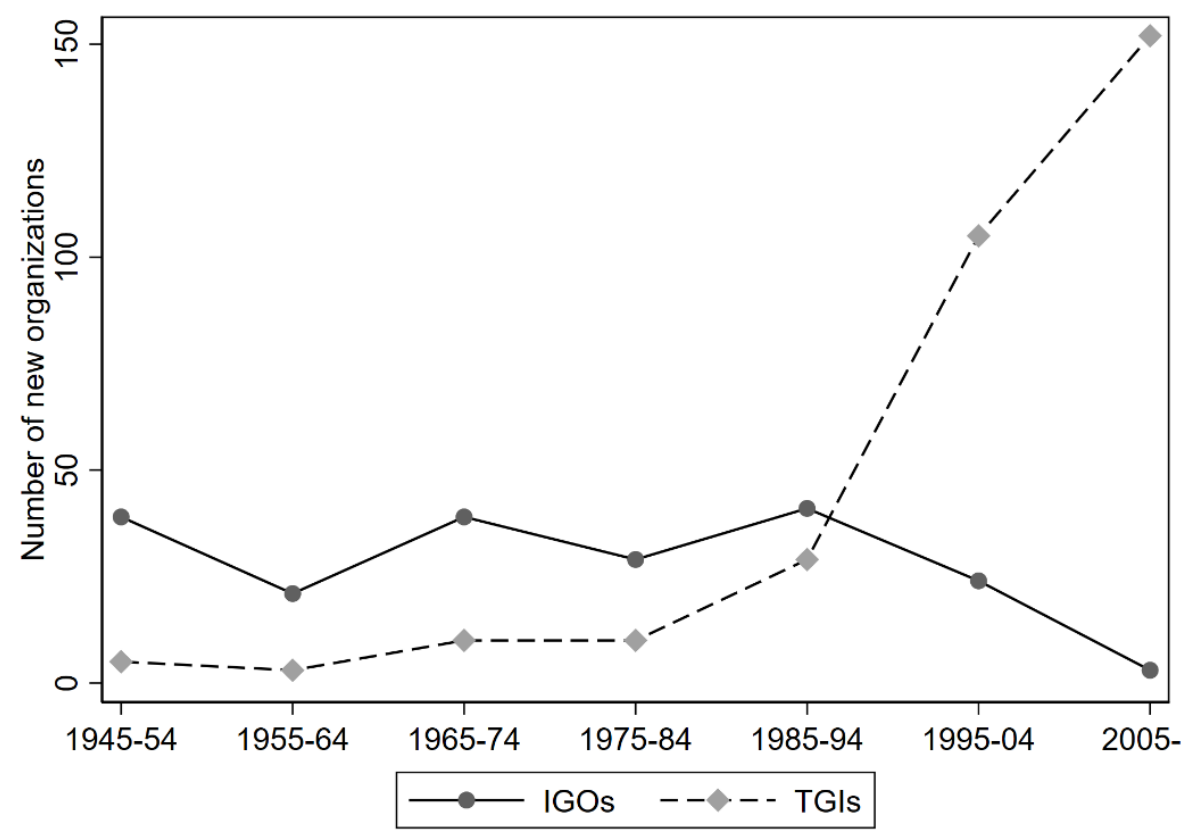

Notes: The figure shows the total number of new organizations created in each time period. 
Table 1: Presence of design features across organizational types in the development regime.

\begin{tabular}{llllll}
\hline & $\begin{array}{l}\text { Independent } \\
\text { secretariat }\end{array}$ & $\begin{array}{l}\text { Voting } \\
\text { mechanism }\end{array}$ & $\begin{array}{l}\text { Monitoring } \\
\text { mechanism }\end{array}$ & $\begin{array}{l}\text { Enforcement } \\
\text { mechanism }\end{array}$ & $\begin{array}{l}\text { Dispute } \\
\text { settlement } \\
\text { number of } \\
\text { design features }\end{array}$ \\
\hline IGO & 0.62 & 0.69 & 0.27 & 0.19 & 0.42 \\
IIGO & 0.50 & 0.25 & 0.19 & 0.08 & 0.04 \\
TGI & 0.27 & 0.23 & 0.18 & 0.06 & 0.07 \\
\hline
\end{tabular}

Notes: Column margins refer to specific design features over all organizations. Row margins refer to all organizations of the same type. 
Table 2: Summary statistics.

\begin{tabular}{llllll}
\hline Variable & Observations & Mean & Sd & Min & Max \\
\hline $\begin{array}{l}\text { Dependent variables } \\
\text { TGI }\end{array}$ & 510 & & & & \\
Independent variables & & 0.62 & 0.49 & 0.00 & 1.00 \\
Number of issues & 559 & & & & \\
Member states & 532 & 1.02 & 0.49 & 0.00 & 2.30 \\
Preference heterogeneity & 447 & 2.11 & 1.33 & 0.00 & 5.27 \\
Power & 424 & 1.88 & 1.44 & 0.00 & 4.98 \\
Power difference & 365 & 26.38 & 2.45 & 18.60 & 30.53 \\
Polity IV & 476 & 27.45 & 2.70 & 18.44 & 30.56 \\
Polity IV difference & 476 & 4.85 & 5.21 & -9.50 & 10.00 \\
Most-similar previous IO & 498 & 9.88 & 8.06 & 0.00 & 20.00 \\
States in system & 559 & 0.78 & 0.14 & 0.31 & 1.00 \\
System growth & 559 & 5.07 & 0.33 & 3.50 & 5.27 \\
\hline
\end{tabular}

Notes: Descriptive statistics for a selection of variables. Please refer to the supplemental appendix for the full list of variables along with definitions and data sources. 
Table 3: Arbitrating among different explanations of institutional design.

\begin{tabular}{|c|c|c|c|c|}
\hline & $(1)$ & $(2)$ & $(3)$ & (4) \\
\hline \multicolumn{5}{|l|}{ Stage 1: Institutional creation } \\
\hline \multirow[t]{2}{*}{ System growth } & $0.613 * * *$ & $0.627 * * *$ & $0.657 * * *$ & $0.672 * * *$ \\
\hline & $(0.089)$ & $(0.105)$ & $(0.112)$ & $(0.137)$ \\
\hline \multirow[t]{2}{*}{ Number of issues } & $-2.068 * * *$ & $-4.903 * * *$ & $-2.249 * * *$ & $-3.456 * * *$ \\
\hline & $(0.170)$ & (1.199) & $(0.199)$ & $(1.200)$ \\
\hline \multirow[t]{2}{*}{ Member states } & 0.098 & 0.122 & $0.128^{*}$ & $0.166^{*}$ \\
\hline & $(0.075)$ & $(0.081)$ & $(0.075)$ & $(0.095)$ \\
\hline \multirow[t]{2}{*}{ Preference heterogeneity } & $0.265 * * *$ & $0.304 * * *$ & $0.255^{* *}$ & $0.281 * *$ \\
\hline & $(0.093)$ & $(0.105)$ & $(0.108)$ & $(0.122)$ \\
\hline \multirow[t]{2}{*}{ Power } & $-0.106^{* *}$ & $-0.103 * *$ & -0.080 & -0.074 \\
\hline & $(0.046)$ & $(0.052)$ & $(0.054)$ & $(0.063)$ \\
\hline \multirow[t]{2}{*}{ Power difference } & $-0.475 * * *$ & $-0.505 * * *$ & $-0.456 * * *$ & $-0.482 * * *$ \\
\hline & $(0.078)$ & $(0.100)$ & $(0.079)$ & $(0.103)$ \\
\hline \multirow[t]{2}{*}{ Polity IV } & 0.024 & 0.016 & 0.018 & 0.007 \\
\hline & $(0.020)$ & $(0.025)$ & $(0.022)$ & $(0.024)$ \\
\hline \multirow[t]{2}{*}{ Polity IV difference } & -0.003 & -0.010 & -0.012 & -0.019 \\
\hline & $(0.017)$ & $(0.019)$ & $(0.019)$ & $(0.021)$ \\
\hline \multirow[t]{2}{*}{ Most-similar previous IO } & -1.095 & $-1.579 * *$ & -1.067 & $-1.529 * *$ \\
\hline & $(0.707)$ & $(0.689)$ & $(0.686)$ & $(0.643)$ \\
\hline \multicolumn{5}{|l|}{ Stage 2: TGI } \\
\hline \multirow[t]{2}{*}{ Number of issues } & 0.006 & 0.040 & 0.010 & 0.038 \\
\hline & $(0.058)$ & $(0.165)$ & $(0.080)$ & $(0.153)$ \\
\hline \multirow[t]{2}{*}{ Member states } & $-0.065^{* * *}$ & $-0.066 * * *$ & $-0.06 * * *$ & $-0.064 * * *$ \\
\hline & $(0.022)$ & $(0.022)$ & $(0.022)$ & $(0.022)$ \\
\hline \multirow[t]{2}{*}{ Preference heterogeneity } & $0.058 * *$ & $0.039 *$ & $0.046^{*}$ & 0.033 \\
\hline & $(0.026)$ & $(0.023)$ & $(0.025)$ & $(0.023)$ \\
\hline \multirow[t]{2}{*}{ Power } & $0.054 * * *$ & $0.051 * * *$ & $0.042 * *$ & $0.037^{*}$ \\
\hline & $(0.020)$ & $(0.020)$ & $(0.021)$ & $(0.021)$ \\
\hline \multirow[t]{2}{*}{ Power difference } & 0.003 & 0.008 & 0.009 & 0.012 \\
\hline & $(0.018)$ & $(0.018)$ & $(0.019)$ & $(0.021)$ \\
\hline \multirow[t]{2}{*}{ Polity IV } & $0.011 * *$ & $0.009^{*}$ & $0.011 * *$ & $0.010^{*}$ \\
\hline & $(0.005)$ & $(0.005)$ & $(0.005)$ & $(0.005)$ \\
\hline \multirow[t]{2}{*}{ Polity IV difference } & 0.001 & 0.002 & 0.001 & 0.002 \\
\hline & $(0.003)$ & $(0.003)$ & $(0.003)$ & $(0.003)$ \\
\hline \multirow[t]{2}{*}{ Most-similar previous IO } & $-0.316^{* *}$ & $-0.286^{*}$ & $-0.464 * * *$ & $-0.445 * * *$ \\
\hline & $(0.150)$ & $(0.164)$ & $(0.142)$ & $(0.162)$ \\
\hline Control variables & Yes & Yes & Yes & Yes \\
\hline Issue area dummies & No & Yes & No & Yes \\
\hline Governance task dummies & No & No & Yes & Yes \\
\hline N1 & 1216 & 1216 & 1173 & 1173 \\
\hline $\mathrm{N} 2$ & 384 & 384 & 366 & 366 \\
\hline Pseudo-R2 & 0.528 & 0.565 & 0.654 & 0.701 \\
\hline $\mathrm{t}$-value & 0.841 & -0.416 & 0.078 & -0.508 \\
\hline
\end{tabular}

Bivariate probit regressions with robust standard errors. t-values refer to cross-equation correlations.

Significance levels: ${ }^{*} \mathrm{p}<.1 \quad * * \mathrm{p}<.05 \quad * * * \mathrm{p}<.01$. 


\section{Supplemental appendix}

Figure A1: Evolution of the average formalization of international organizations.

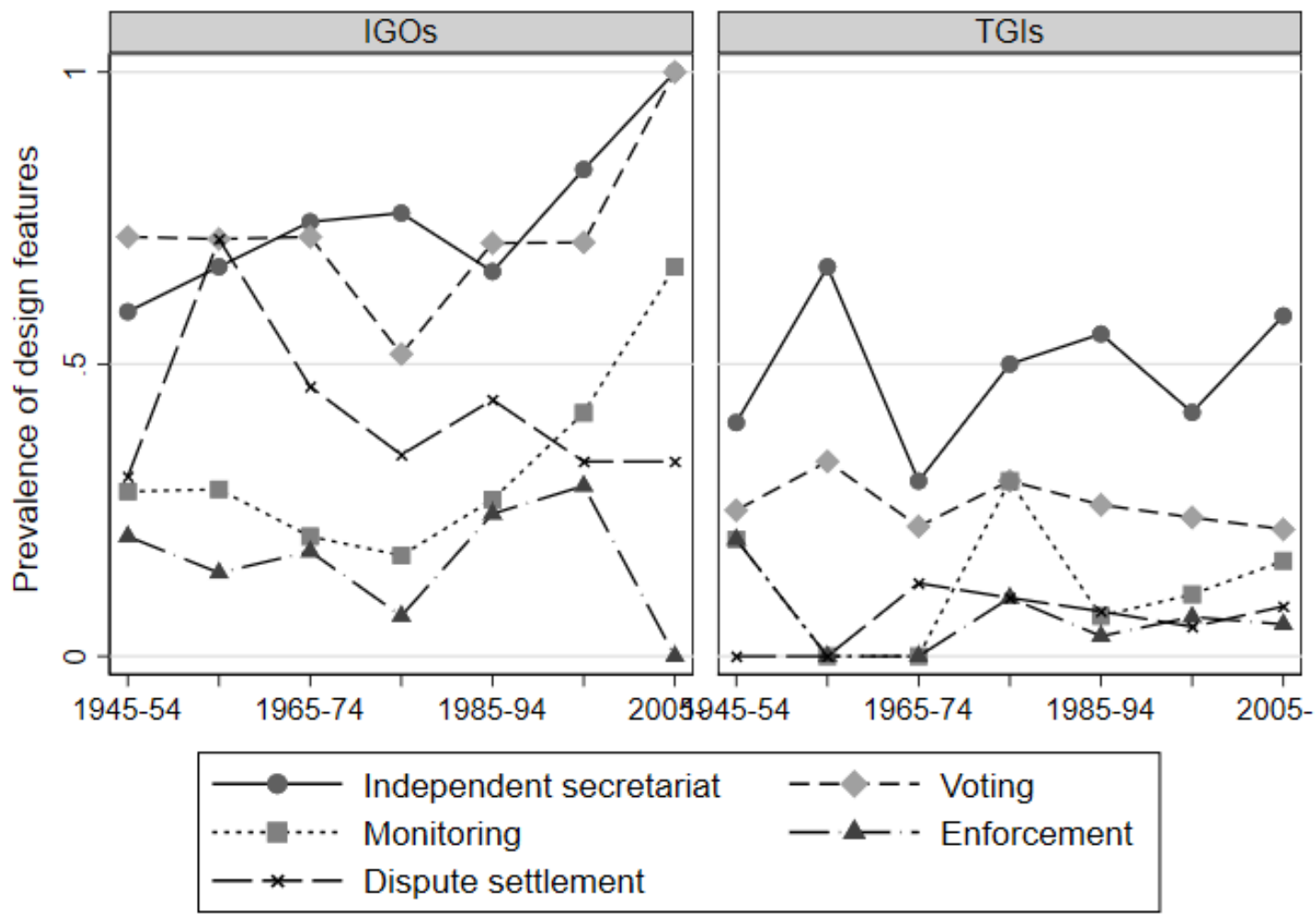


Figure A2: Evolution of functional similarity with the organizational field.
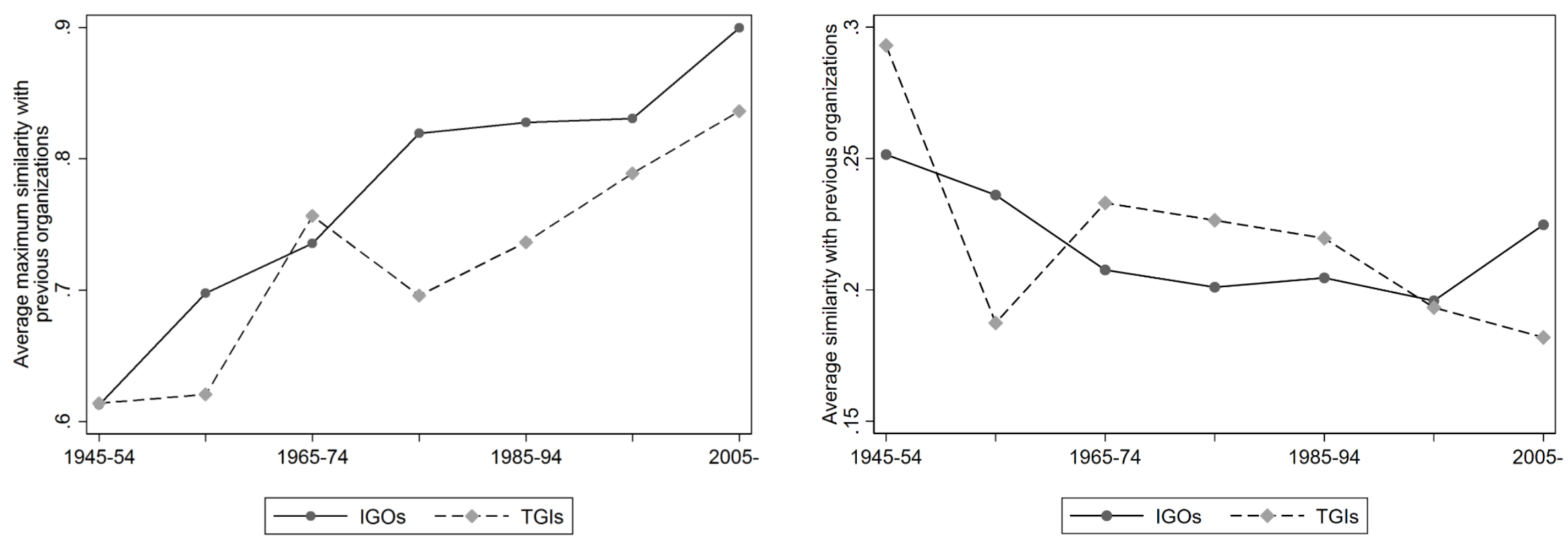

Notes: Both figures track the similarity of new entrants - separately for IGOs and TGIs - with all existing organizations. The left panel shows the maximum similarity with previous organizations based on issue-task combinations for all organizations founded in a given period. The right panel shows the average similarity with previous organizations based on issue-task combinations for all organizations established in the given period.

The patterns in the left-hand panel appear to be consistent with the prevailing narrative of increased task duplication in the multilateral development system. For every new entrant, it has become significantly easier to find an organization that performs similar (if not the same) governance functions in a given issue area.

However, the figure in the right-hand panel suggests that new organizations, and particularly new TGIs, have been established increasingly to fill particular organizational niches because they have become (on average) less alike than existing organizations. 
Table A1: Alternative definition of dependent variable.

\begin{tabular}{|c|c|c|c|c|}
\hline & $(1)$ & $(2)$ & $(3)$ & (4) \\
\hline \multicolumn{5}{|l|}{ Stage 1: Institutional creation } \\
\hline \multirow[t]{2}{*}{ System growth } & $0.625 * * *$ & $0.630 * * *$ & $0.655 * * *$ & $0.674 * * *$ \\
\hline & $(0.087)$ & $(0.104)$ & $(0.111)$ & $(0.133)$ \\
\hline \multirow[t]{2}{*}{ Number of issues } & $-2.102 * * *$ & $-4.822 * * *$ & $-2.266 * * *$ & $-3.432 * * *$ \\
\hline & $(0.168)$ & $(1.219)$ & $(0.202)$ & $(1.202)$ \\
\hline \multirow[t]{2}{*}{ Member states } & 0.092 & 0.120 & $0.126^{*}$ & $0.167^{*}$ \\
\hline & $(0.074)$ & $(0.081)$ & $(0.075)$ & $(0.094)$ \\
\hline \multirow[t]{2}{*}{ Preference heterogeneity } & $0.268 * * *$ & $0.309 * * *$ & $0.253 * *$ & $0.286^{* *}$ \\
\hline & $(0.095)$ & $(0.105)$ & $(0.108)$ & $(0.120)$ \\
\hline \multirow[t]{2}{*}{ Power } & $-0.106^{* *}$ & $-0.104 * *$ & -0.082 & -0.076 \\
\hline & $(0.046)$ & $(0.052)$ & $(0.053)$ & $(0.062)$ \\
\hline \multirow[t]{2}{*}{ Power difference } & $-0.472 * * *$ & $-0.506^{* * *}$ & $-0.452 * * *$ & $-0.485 * * *$ \\
\hline & $(0.078)$ & $(0.100)$ & $(0.079)$ & $(0.101)$ \\
\hline \multirow[t]{2}{*}{ Polity IV } & 0.026 & 0.016 & 0.019 & 0.008 \\
\hline & $(0.020)$ & $(0.025)$ & $(0.023)$ & $(0.024)$ \\
\hline \multirow[t]{2}{*}{ Polity IV difference } & -0.002 & -0.011 & -0.012 & -0.019 \\
\hline & $(0.018)$ & $(0.019)$ & $(0.019)$ & $(0.021)$ \\
\hline \multirow[t]{2}{*}{ Most-similar previous IO } & -1.066 & $-1.595 * *$ & -1.074 & $-1.527 * *$ \\
\hline & $(0.699)$ & $(0.681)$ & $(0.683)$ & $(0.654)$ \\
\hline \multicolumn{5}{|l|}{ Stage 2: TGI } \\
\hline \multirow[t]{2}{*}{ Number of issues } & -0.074 & $0.255^{*}$ & -0.024 & 0.160 \\
\hline & $(0.060)$ & $(0.140)$ & $(0.062)$ & $(0.138)$ \\
\hline \multirow[t]{2}{*}{ Member states } & $-0.074 * *$ & $-0.070 * * *$ & $-0.070 * *$ & $-0.068 * * *$ \\
\hline & $(0.033)$ & $(0.026)$ & $(0.031)$ & $(0.026)$ \\
\hline \multirow[t]{2}{*}{ Preference heterogeneity } & 0.040 & 0.027 & 0.037 & 0.026 \\
\hline & $(0.027)$ & $(0.023)$ & $(0.027)$ & $(0.024)$ \\
\hline \multirow[t]{2}{*}{ Power } & $0.071 * * *$ & $0.061 * * *$ & $0.054 * *$ & $0.046^{* *}$ \\
\hline & $(0.024)$ & $(0.021)$ & $(0.023)$ & $(0.022)$ \\
\hline \multirow[t]{2}{*}{ Power difference } & 0.020 & 0.010 & 0.019 & 0.012 \\
\hline & $(0.018)$ & $(0.017)$ & $(0.018)$ & $(0.020)$ \\
\hline \multirow[t]{2}{*}{ Polity IV } & 0.008 & 0.007 & 0.008 & 0.008 \\
\hline & $(0.005)$ & $(0.005)$ & $(0.005)$ & $(0.005)$ \\
\hline \multirow[t]{2}{*}{ Polity IV difference } & -0.002 & 0.002 & -0.001 & 0.001 \\
\hline & $(0.003)$ & $(0.003)$ & $(0.003)$ & $(0.003)$ \\
\hline \multirow[t]{2}{*}{ Most-similar previous IO } & -0.220 & $-0.345^{* *}$ & $-0.436^{* * *}$ & $-0.503 * * *$ \\
\hline & $(0.154)$ & $(0.156)$ & $(0.148)$ & $(0.157)$ \\
\hline Control variables & Yes & Yes & Yes & Yes \\
\hline Issue area dummies & No & Yes & No & Yes \\
\hline Governance task dummies & No & No & Yes & Yes \\
\hline N1 & 1216 & 1216 & 1173 & 1173 \\
\hline $\mathrm{N} 2$ & 433 & 433 & 390 & 390 \\
\hline Pseudo-R2 & 0.436 & 0.556 & 0.624 & 0.711 \\
\hline $\mathrm{t}$-value & $-2.131 * *$ & -0.911 & -1.515 & -0.543 \\
\hline
\end{tabular}


Bivariate probit regressions for whether states created organization (Stage 1) and whether a created organization was a TGI (Stage 2). Covariates for organizations that never came into existence obtained through multiple imputation. Contrary to the main analysis, relevant comparisons in the second stage are made against any IGO or IIGO.

Significance levels: $* \mathrm{p}<0.10, * * \mathrm{p}<0.05, * * * \mathrm{p}<0.01$ 
Table A2: Sequential analysis of design determinants with fixed effects.

\begin{tabular}{|c|c|c|c|c|}
\hline & $(1)$ & (2) & (3) & (4) \\
\hline \multicolumn{5}{|l|}{ Stage 1: Institutional creation } \\
\hline System growth & $\begin{array}{l}0.613 * * * \\
(0.100)\end{array}$ & $\begin{array}{l}0.592 * * * \\
(0.137)\end{array}$ & $\begin{array}{l}0.594 * * * \\
(0.106)\end{array}$ & $\begin{array}{l}0.587 * * * \\
(0.104)\end{array}$ \\
\hline Number of issues & $\begin{array}{l}-3.725 * * * \\
(0.953)\end{array}$ & & & \\
\hline Member states & $\begin{array}{l}0.131^{*} \\
(0.074)\end{array}$ & & & \\
\hline Preference heterogeneity & $\begin{array}{l}-0.075^{*} \\
(0.045)\end{array}$ & & & \\
\hline Power & & $\begin{array}{l}-0.080 \\
(0.051)\end{array}$ & & \\
\hline Power difference & & $\begin{array}{l}-0.339 * * * \\
(0.060)\end{array}$ & & \\
\hline Polity IV & & & $\begin{array}{l}-0.035^{* * *} \\
(0.013)\end{array}$ & \\
\hline Polity IV difference & & & $\begin{array}{l}-0.003 \\
(0.009)\end{array}$ & \\
\hline Most-similar previous IO & & & & $\begin{array}{l}-1.105^{* * *} \\
(0.413)\end{array}$ \\
\hline
\end{tabular}

Stage 2: TGI

Number of issues

0.017

(0.147)

Member states

$-0.110 * * *$

(0.021)

Preference heterogeneity

(0.015)

Power

$0.066^{* * *}$

$(0.017)$

Power difference

0.011

(0.015)

Polity IV

$0.016^{* * *}$

$(0.004)$

Polity IV difference

$-0.001$

(0.002)

Most-similar previous IO

$-0.409 * * *$

(0.127)

Control variables

Issue area dummies

Governance task dummies

N1

$\mathrm{N} 2$

11

$\mathrm{t}$

\begin{tabular}{llll} 
Yes & Yes & Yes & Yes \\
Yes & Yes & Yes & Yes \\
Yes & Yes & Yes & Yes \\
1491 & 1173 & 1491 & 1491 \\
483 & 366 & 483 & 483 \\
446.46 & 305.41 & 480.76 & 489.99 \\
-0.86 & -1.30 & -0.20 & 0.33 \\
\hline
\end{tabular}

Bivariate probit regressions for whether states created organization (Stage 1) and whether a created organization was a TGI (Stage 2). Covariates for organizations that never came into existence obtained through multiple imputation. Relevant comparisons in the second stage are made against any IGO. 
Significance levels: $* \mathrm{p}<0.10,{ }^{* *} \mathrm{p}<0.05,{ }^{* * *} \mathrm{p}<0.01$. 
Table A3: Sequential analysis of design determinants with fixed effects.

\begin{tabular}{|c|c|c|c|c|}
\hline & $(1)$ & (2) & (3) & (4) \\
\hline \multicolumn{5}{|l|}{ Stage 1: Institutional creation } \\
\hline System growth & $\begin{array}{l}0.616^{* * *} \\
(0.101)\end{array}$ & $\begin{array}{l}0.598 * * * \\
(0.135)\end{array}$ & $\begin{array}{l}0.595 * * * \\
(0.106)\end{array}$ & $\begin{array}{l}0.586 * * * \\
(0.105)\end{array}$ \\
\hline Number of issues & $\begin{array}{l}-3.711 * * * \\
(0.962)\end{array}$ & & & \\
\hline Member states & $\begin{array}{l}0.134 * \\
(0.073)\end{array}$ & & & \\
\hline Preference heterogeneity & $\begin{array}{l}-0.073 \\
(0.046)\end{array}$ & & & \\
\hline Power & & $\begin{array}{l}-0.084 \\
(0.051)\end{array}$ & & \\
\hline Power difference & & $\begin{array}{l}-0.34 * * * \\
(0.061)\end{array}$ & & \\
\hline Polity IV & & & $\begin{array}{l}-0.036 * * * \\
(0.013)\end{array}$ & \\
\hline Polity IV difference & & & $\begin{array}{l}-0.003 \\
(0.009)\end{array}$ & \\
\hline Most-similar previous IO & & & & $\begin{array}{l}-1.106^{* * *} \\
(0.414)\end{array}$ \\
\hline
\end{tabular}

\begin{tabular}{ll}
\hline Stage 2: TGI & 0.149 \\
Number of issues & $(0.137)$ \\
& $-0.118^{* * *}$ \\
Member states & $(0.026)$ \\
& $0.052^{* * *}$ \\
Preference heterogeneity & $(0.017)$
\end{tabular}

Power

$0.079 * * *$

$(0.017)$

Power difference

0.007

(0.015)

Polity IV

$0.016^{* * *}$

$(0.004)$

Polity IV difference

$-0.003$

(0.002)

Most-similar previous IO

$-0.466 * * *$

(0.127)

$\begin{array}{lllll}\text { Control variables } & \text { Yes } & \text { Yes } & \text { Yes } & \text { Yes } \\ \text { Issue area dummies } & \text { Yes } & \text { Yes } & \text { Yes } & \text { Yes } \\ \text { Governance task dummies } & \text { Yes } & \text { Yes } & \text { Yes } & \text { Yes } \\ \text { N1 } & 1491 & 1173 & 1491 & 1491 \\ \text { N2 } & 507 & 390 & 507 & 507 \\ 11 & 480.538 & 329.996 & 515.878 & 527.229 \\ \mathrm{t} & -0.085 & -1.473 & -0.327 & 0.276\end{array}$

Bivariate probit regressions for whether states created organization (Stage 1) and whether a created organization was a TGI (Stage 2). Covariates for organizations that never came into existence obtained through multiple imputation. Relevant comparisons in the second stage are made against any IGO or IIGO. 
Significance levels: $* \mathrm{p}<0.10,{ }^{* *} \mathrm{p}<0.05,{ }^{* * *} \mathrm{p}<0.01$. 
Table A4: Sequential analysis of design determinants with continuous dependent variable.

\begin{tabular}{|c|c|c|c|c|}
\hline & $(1)$ & (2) & $(3)$ & (4) \\
\hline \multicolumn{5}{|c|}{ Stage 1: Institutional creation } \\
\hline System growth & $\begin{array}{l}0.618^{* * *} \\
(0.101)\end{array}$ & $\begin{array}{l}0.612 * * * \\
(0.132)\end{array}$ & $\begin{array}{l}0.599 * * * \\
(0.107)\end{array}$ & $\begin{array}{l}0.593 * * * \\
(0.105)\end{array}$ \\
\hline Number of issues & $\begin{array}{l}-3.709 * * * \\
(0.958)\end{array}$ & & & \\
\hline Member states & $\begin{array}{l}0.133^{*} \\
(0.072)\end{array}$ & & & \\
\hline Preference heterogeneity & $\begin{array}{l}-0.073 \\
(0.046)\end{array}$ & & & \\
\hline Power & & $\begin{array}{l}-0.080 \\
(0.052)\end{array}$ & & \\
\hline Power difference & & $\begin{array}{l}-0.341 * * * \\
(0.061)\end{array}$ & & \\
\hline Polity IV & & & $\begin{array}{l}-0.035 * * * \\
(0.013)\end{array}$ & \\
\hline Polity IV difference & & & $\begin{array}{l}-0.002 \\
(0.009)\end{array}$ & \\
\hline Most-similar previous IO & & & & $\begin{array}{l}-1.107 * * * \\
(0.413)\end{array}$ \\
\hline
\end{tabular}

Stage 2: TGI

Number of issues

$0.812 * *$

(0.386)

Member states

$0.176^{* *}$

$(0.077)$

Preference heterogeneity

$-0.040$

$(0.061)$

Power

$-0.090$

$(0.077)$

Power difference

0.020

(0.066)

Polity IV

0.001

$(0.016)$

Polity IV difference

$0.024 * * *$

$(0.008)$

Most-similar previous IO

(0.471)

\begin{tabular}{lllll}
\hline Control variables & Yes & Yes & Yes & Yes \\
Issue area dummies & Yes & Yes & Yes & Yes \\
Governance task dummies & Yes & Yes & Yes & Yes \\
N1 & 1491 & 1173 & 1491 & 1491 \\
N2 & 507 & 390 & 507 & 507 \\
11 & 1160.23 & 850.10 & 1184.81 & 1185.40 \\
$\mathrm{t}$ & -0.65 & -1.21 & $-1.89 *$ & $-2.69 * * *$ \\
\hline
\end{tabular}

Bivariate probit regressions for whether states created organization (Stage 1) and an index of organizational structure (Stage 2). Signs of covariates must be reversed to support the theory. Covariates for organizations that never came into existence obtained through multiple imputation. 
Significance levels: $* \mathrm{p}<0.10,{ }^{* *} \mathrm{p}<0.05,{ }^{* * *} \mathrm{p}<0.01$. 
Table A5: Alternative way of generating unobserved organizations

\begin{tabular}{lllll}
\hline & $(1)$ & $(2)$ & $(3)$ & $(4)$ \\
\hline Stage 2: TGI & & & & \\
Number of issues & $-0.143^{* * *}$ & 0.173 & -0.079 & 0.117 \\
& $(0.048)$ & $(0.136)$ & $(0.049)$ & $(0.127)$ \\
Member states & $-0.081^{* * *}$ & $-0.068^{* * *}$ & $-0.085^{* * *}$ & $-0.077^{* * *}$ \\
& $(0.026)$ & $(0.022)$ & $(0.023)$ & $(0.023)$ \\
Preference heterogeneity & $0.049^{* *}$ & 0.028 & $0.047^{* *}$ & 0.027 \\
& $(0.022)$ & $(0.019)$ & $(0.022)$ & $(0.02)$ \\
Power & $0.054^{* *}$ & $0.05^{* *}$ & $0.038^{*}$ & 0.034 \\
& $(0.021)$ & $(0.02)$ & $(0.022)$ & $(0.021)$ \\
Power difference & 0.013 & 0.007 & 0.016 & 0.012 \\
& $(0.017)$ & $(0.016)$ & $(0.016)$ & $(0.015)$ \\
Polity IV & $0.011^{* *}$ & $0.009^{*}$ & $0.011^{* *}$ & $0.01 *$ \\
& $(0.005)$ & $(0.005)$ & $(0.005)$ & $(0.005)$ \\
Polity IV difference & -0.002 & 0.001 & -0.001 & 0.001 \\
& $(0.004)$ & $(0.003)$ & $(0.003)$ & $(0.003)$ \\
Most-similar previous IO & -0.188 & $-0.319^{* *}$ & $-0.473^{* * *}$ & $-0.557^{* * *}$ \\
& $(0.166)$ & $(0.151)$ & $(0.159)$ & $(0.15)$ \\
\hline Observations & 430 & 430 & 389 & 389 \\
R-squared & 0.528 & 0.565 & 0.654 & 0.701 \\
Cross-correlation & $2.296^{* *}$ & $1.695^{*}$ & 1.137 & 0.321 \\
Issue area dummies & No & Yes & No & Yes \\
Task dummies & No & No & Yes & Yes \\
\hline
\end{tabular}

Bivariate probit regressions for whether states created organization (Stage $1-$ not shown) and whether an organization was a TGI (Stage 2). First stage omitted in the table because by construction the coefficients are insignificant because organizations with the same features simultaneously do exist (in the design they were created) and do not exist (in the design in which they were not created).

Significance levels: $* \mathrm{p}<0.10,{ }^{* *} \mathrm{p}<0.05, * * * \mathrm{p}<0.01$. 
Table A6: Variable definitions and descriptive statistics.

\begin{tabular}{|c|c|c|c|c|c|c|}
\hline Variable & Definition and sources & Observations & Mean & $\mathrm{Sd}$ & Min & Max \\
\hline \multicolumn{7}{|l|}{ Dependent variable } \\
\hline TGI & $\begin{array}{l}1 \text { if TGI. In the main analysis, the relevant comparison is against IGOs; for } \\
\text { robustness tests, the comparison is against IGOs or IIGOs (for which the } \\
\text { mean is lower but the other statistics are similar) }\end{array}$ & 510 & 0.62 & 0.49 & 0.00 & 1.00 \\
\hline Organizational structure & $\begin{array}{l}\text { Number of structural features: secretariat, voting provision, monitoring } \\
\text { mechanism, enforcement mechanism, dispute settlement }\end{array}$ & 559 & 1.39 & 1.37 & 0.00 & 5.00 \\
\hline \multicolumn{7}{|l|}{ Key predictors } \\
\hline Number of issues & $\begin{array}{l}\text { Natural logarithm of the number of issues in which a given organization is } \\
\text { active. }\end{array}$ & 559 & 1.02 & 0.49 & 0.00 & 2.30 \\
\hline Member states & Natural logarithm of the number of member states of a given organization. & 532 & 2.11 & 1.33 & 0.00 & 5.27 \\
\hline Preference heterogeneity & $\begin{array}{l}\text { Maximum difference in the ideal point difference (based on UNGA voting } \\
\text { patterns) across the member states of an organization. }\end{array}$ & 447 & 1.88 & 1.44 & 0.00 & 4.98 \\
\hline Power & $\begin{array}{l}\text { Natural logarithm of the average GDP across the member states of an } \\
\text { organization. }\end{array}$ & 424 & 26.38 & 2.45 & 18.60 & 30.53 \\
\hline Power difference & $\begin{array}{l}\text { Natural logarithm of the difference in GDP between the largest member and } \\
\text { the smallest member of an organization. }\end{array}$ & 365 & 27.45 & 2.70 & 18.44 & 30.56 \\
\hline Polity IV & Average Polity IV index across the member states of an organization. & 476 & 4.85 & 5.21 & -9.50 & 10.00 \\
\hline Polity IV difference & $\begin{array}{l}\text { Difference in Polity IV index between the most democratic member and the } \\
\text { most autocratic member of an organization. }\end{array}$ & 476 & 9.88 & 8.06 & 0.00 & 20.00 \\
\hline Most-similar previous IO & $\begin{array}{l}\text { Most-similar previous organization is computed with data available from the } \\
\text { TGIWP and original coding for this article of issue areas and task profiles for }\end{array}$ & 498 & 0.78 & 0.14 & 0.31 & 1.00 \\
\hline
\end{tabular}
non-TGIs as follows. First, for each organization, the set of previous organizations is identified and their respective profiles for issue areas and governance tasks extracted. Second, the cosine similarity between any two profiles (corresponding to each pair of the given organization and a previous organization) for both issue areas and governance task is computed and both values multiplied with each other. Third, the maximum value over all pairs is 
identified.

States in system

System growth
Natural logarithm of the number of states in the international system.

Natural logarithm of the number of new (other) organizations created in the

foundation year of a given organization. 
Appendix B: List of interviews.

\#1 Senior Special Fellow and Training Adviser at UNITAR

May 20, 2016

\#2 Former Executive Secretary of IFCS

May 25, 2018

\#3 Former staff member, UNITAR, Chemicals and Waste Management Program May 25, 2018 